Article

\title{
Geological and Geomorphological Controls on the Path of an Intermountain Roman Road: The Case of the Via Herculia, Southern Italy
}

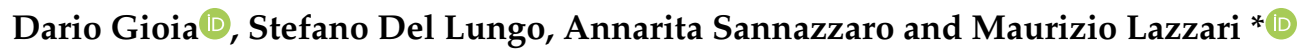 \\ CNR-Istituto per i Beni Archeologici e Monumentali (IBAM), C/da S. Loja, 85050 Potenza, Italy \\ * Correspondence: m.lazzari@ibam.cnr.it; Tel.: +39-0971-427326
}

Received: 16 July 2019; Accepted: 10 September 2019; Published: 12 September 2019

\begin{abstract}
This work introduces the results of a geoarchaeological study about a large segment of a Roman road (i.e., Via Herculia, III and the beginning of IV century A.D.), which crossed the Lucanian segment of the southern Apennines (Italy). Classical approach of the archaeological research based on the analysis of bibliographic, archival, literary, archaeological, and historical sources allowed us to infer the Roman road path, which is quite different from previous hypotheses. Geoarchaeological analysis is based on the detailed mapping of lithological and geomorphological features of the study area and has been primarily focused on a well-known segment of the Roman road from Filiano to the southern mountains of the Potenza city (Sasso di Castalda). Our results suggest that the choice of the road path has been driven by the outcrop of some deposits and the presence of specific geomorphological landforms, such as low-relief areas in mountain landscape. Then, the same approach was applied to a sector with controversial archaeological evidences (i.e., the Upper Agri river valley), where geological and geomorphological analyses support archaeological research in the reconstruction of the ancient path. This integrated approach can help archaeology to understand and then discover ancient road paths crossing complex and impervious landscapes such as the intramontane lands.
\end{abstract}

Keywords: geoarchaeology; geomorphology; Roman roads; Via Herculia; southern Apennines

\section{Introduction}

Due to its important role on economic exchange, information transfer, army movement, control of the territory, and growing of settlement networks, the reconstruction of ancient viability is an important issue for the investigation of past political, social, economic, and military factors of the Roman civilization [1]. The issue of viability is critical, since it is often related to the morphology of a given territory, as well as, conversely, the social and economic growth of a population is necessarily connected to a road network [2-5].

Apart from the economic and political factors promoting the development of an ancient viability, the road planning can be strongly influenced by geological and physiographic features of a territory, such as spatial distribution of rocks or deposits useful for road construction or the presence of specific geomorphological features. Thus, a comprehensive study of a Roman road should include a multidisciplinary approach, where archaeological analysis should be linked to the geological and geomorphological investigation. Usually, archaeologists have some difficulties to find and understand ancient roads when they cross an inland mountainous area. In fact, it is easier to lose the archaeological evidence of a path, confused among multiple variants. Paradoxically, the notoriety of a way, as Appia for example, can be inversely proportional to the degree of preservation of its vestiges in these areas (like in the Irpinia mountains and valleys). Maybe there are many possible paths, but no one will have 
distinguishing and useful signs to attribute its identity confidently. The interdisciplinary comparison of archaeology and geology introduces new elements of analysis and can support archaeological analysis to understand underestimated aspects of the landscape, such as outcrop of extractable rocks, slope profiles, mass movement processes, degree of soil permeability, and the features of drainage networks.

The aim of this work is to investigate the possible influence of geological and geomorphological features on the selection of the path of an intermountain roman road.

Via Herculia was built in the III century A.D. in 311 and then renovated by the emperor Maxentius. Its path has been reconstructed on the basis of a detailed historical and archaeological analysis (i.e., bibliographic, archival, literary, archaeological, and historical sources integrated by extensive field survey and photo-interpretation [6,7]). It changes the traditional idea of an ancient road without certain archaeological control points.

A preliminary geoarchaeological analysis has been carried out along the whole segment of the Roman road located in the western sector of the Basilicata region (see frame in Figure 1), whereas a deeper investigation based on both a detailed geological and geomorphological mapping and quantitative geomorphological analysis has been performed on a 46-km-length key-sector of the axial zone of the chain, from Filiano to Sasso di Castalda villages (Figure 1).

Geological and geomorphological analysis of the archaeologically reconstructed road path and surrounding have been performed in order to infer the possible influence of "positive" and "negative" factors in the road planning, such as local lithological, morphological, and hydrological features [8]. Therefore, all these factors have been analyzed in the complex geoarchaeological setting of the upper Agri river valley, where archaeologists hypothesize four alternative road paths with both similar archaeological constraints and the same distance in roman miles from the last stop-over of Acidios (near Marsico Nuovo town) to the terminus of Grumentum (i.e., the roman colony near Grumento Nova town). 


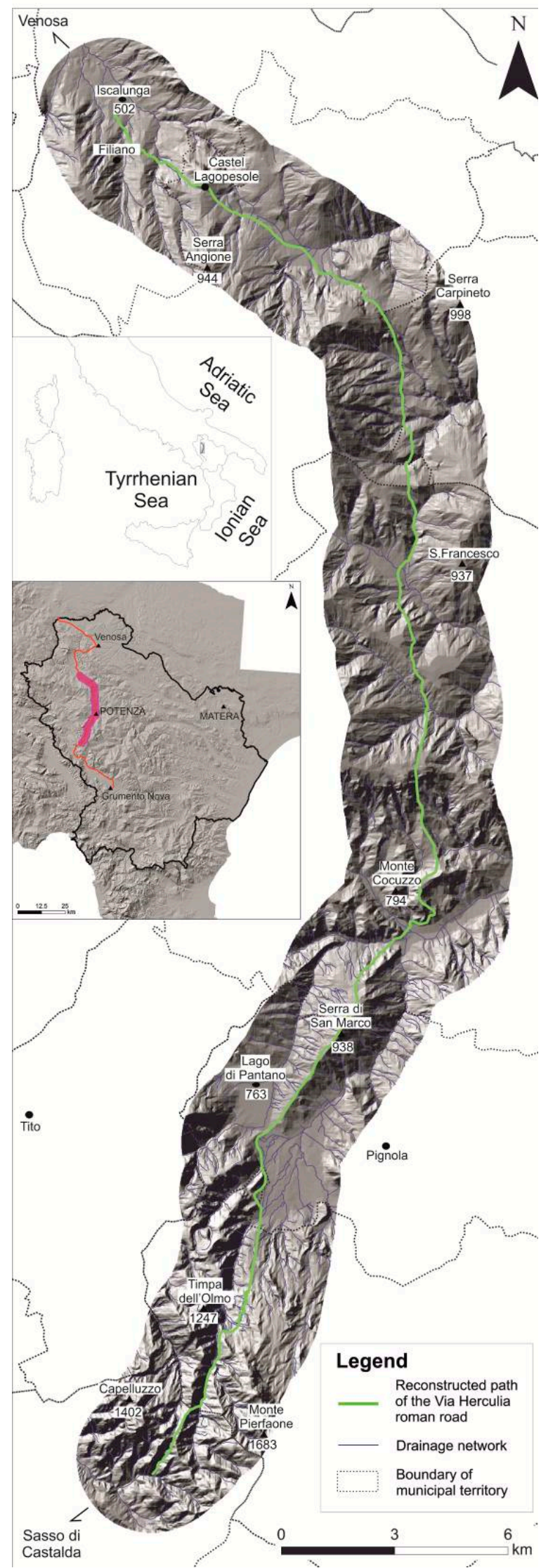

Figure 1. Hillshade of the study area with the location of the reconstructed path of the Roman road in the central sector of the Basilicata region. In the inset: Regional geographical framework of the study area. 


\section{Ancient Intermountain Roads: An Archaelological Overview}

In classical antiquity, the passage of a road in high-relief areas (inter montes) has never been appreciated. Morphological variability gives problems that normally are not considered in open territories. In the V-shaped valleys, the narrow visual prevents from looking further. Finally, when a panorama opens the places, they appear closer than they actually are. The difficulty to calculate distances also prevents appreciation of the path and "real" distance to the next stop. The problem is obviously reflected in the composition of the itinerary sources, writing greater distances that can be more prone to errors.

There the obstacles increase and are of different types according to the seasons (snowfall and frost in winter, avalanches and swell of the streams in spring, reduction of the availability of water in summer, collapses and landslides in autumn under the rain). There are also a lot of possibilities to find significant gradients, also on rather long segments. The low degree of preservation of ancient roads is controlled by these factors and therefore, the identification of archaeological evidences can be complicated.

The problems and the attitude produced by this kind of environment are well explained in the Livian exposition about the crossing of the Alps that Hannibal and the Carthaginian army perform in September 218 B.C. (Liv., XXI, 32.6-37.6).

This happens at the beginning of the Roman warm period. This better climatic condition in the northern hemisphere allows roads, like Flaminia in the difficult pass of Scheggia (northern Umbria) and Salaria in the upper Velino valley (northeastern Lazio), to go along dangerous river engravings with straight stretches and hairpin bends. Via Appia in the valley of S. Andrea (Itri, LT) has a wide road seat (6.6 and $4.2 \mathrm{~m}$ in width, respectively, in the planting phases of the late IV century B.C. and the beginning III D.C.). The use of barriers, canals, terraces, bridges, and sewers to regulate the water flow in excess is limited to a few vulnerable points, susceptible to landslides [9].

Strabo (IV, 6, 6 C204) writes an interesting description of the road traffic in this type of territory [10]. The Alps are taken as a reference and comparison due to the extreme conditions offered (masses of rocks and enormous vertical scarp, constant danger of collapses, slippery stones, chasms, enormous layers capable of intercepting a whole caravan). They are useful to understand the difficulties encountered by the road construction also in a mountainous context of the Italic peninsula.

Along the Apennines, in fact, and particularly in southern Italy, the conditions and dangers are not very different. Between the end of the IV and the III century B.C., the Roman advance faces Sanniti and Lucani with great difficulties. They are the undisputed dominators of the mountains. The extension of the Appia from Capua to Brindisi (after 241 B.C.), passing through Venosa and Taranto, encounters many difficulties. It takes place in 191 B.C., after more than a century from the beginning of its plan.

Strabo (VI, 3, 7 C 282-283) recalls its use for Brindisi if you have to travel mainly on wagons, with a speed variable from 5 to 6.5 roman miles per hour according to the shot type (oxen, mules, or horses). As an alternative, you follow the 'Mule track' (gr. Hêmionikè) from Benevento and Canosa, passing right through the lands of the Sanniti. The official name (Via Minucia, given in 221 B.C.) does not appear there. The brevity of the path (a day or less of travel) and the practicability with pack animals prevail, but the average of the miles decreases from 35 to 19 per day. The asperities of the Irpinia mountains entail a decidedly narrow road seat. There are relevant slopes exceeding the threshold of $8 \%$, established for the movement of a fully laden wagon, and suspended passages are not crossable without animals and expert guides.

Traianus in 109 D.C. will turn this road, then known as (Appia) Traiana, into a comfortable and shorter alternative to this Mule track. The short expression Viam et pontes... fecit, repeated many times in milestones and honorary epigraphs (type CIL, IX, 6005 and 6012; [11]), does not explain the large investments and all infrastructures (cuts, bridges, ramps, terraces, levelling, drains, sewers, canals) or even simply the lateral crepidines (sidewalks), as specified by others (CIL, IX, 442, from Venosa), indispensable to make a road safe, comfortable, and durable. 
A previous example is the famous Lapis Pollae (CIL, X, 6950) of the second half of II century B.C. The honorary inscription is elevated in a stop-over (Borgo S. Pietro, near Polla, SA) of the via Ab Regio ad Capuam. It is located at the beginning of Vallo di Diano and before one of its most complex stretches through the Lucanian Apennine and the Pollino massif. There, the anonymous author writes about the construction of bridges and the measurement of distances, omitting the real difficulties faced. In fact, the road, stretched out over three regions (Campania, Basilicata, and Calabria), is shorter than the Appia (321 roman miles versus 326), but is longer to go than 3 or 4 days, because of the natural obstacles.

Almost contemporaneously, Lucilius (Luc., Sat., III, 109 M) speaks about it, describing a track labosum et lutosum ('tiring and muddy'), because it is in clay and crosses a territory where cold dominates and waters are not controlled, flowing free on the surfaces with inevitable damage of the road. The water is the prevailing element of that landscape, whose italic word *NAR/*NER ('water' and 'river') occurs several times in local place names (for example in Lagonegro and Nerulum, near Castelluccio Inferiore town). It is also in curious paretimologies introduced by the Romans. They modify such names, as for the stop-over of Nares Lucanae, or 'lucanian rivers' (Cic., ad Att., III, 2; Tab. Peut., Segm. VI. 2); that is, the cross of Marmo-Platano and Tanagro gorges nicknamed nares ('nostrils') in latin [12]. Generally, the road level ground does not have the regularity found in the first 14 miles at least, crossing the suburb of Rome, and it can change from one stretch to another. The rigid distinction laid down by the Republican censores (Liv., XLI, 27, 5) between urban sections, paved in stone (vias sternendas in silice in Urbe), and extra urbem, swallowed, cobbled (glarea... substruendas marginandasque), or also dirt (terrena; Ulp., in D., XLIII, 11.1.2), does not really exist.

The use of stone (leucitite for the so-called 'basoli' but also leucotefrite, lithoid travertine, and limestone, depending on local availability) starts in the III century B.C. with an increase in the II. At the same time, there are bridges and viaducts in opus quadratum. Outside the towns, the canonical width of the roads changes from 3.8-3.9 m (14 italic feet) to 4.1-4.2 $\mathrm{m}$ of the corresponding Roman feet. In Central Italy, Via Salaria [13] and Flaminia show it. The latter, build up in 220 B.C. with a single road yard extended on 210 miles from Rome to Rimini and with many infrastructures (cut, viaducts, bridges, ramps, structures, terraces, canals, pipelines, sewers) [14], is characterized by different types of paving (stratum) and background according to the only criterion of the local availability of materials (silice and limestone into a settlement; cobblestone, gravel, and clay outside, as for example in Carsulae, Port N or Arco di S. Damiano).

In the inner mountain sectors, this road construction method is even more evident and also has a direct comparison in similar coastal contexts, where the cliffs overlooking the sea show the same problems and produce the same solutions. The variation of stratum is functional to the resistance required for the type of traffic it has to sustain. The overcoming of a marshy environment, that in the plains and in the coastal areas is done laying down amphorae, in a mountain context is facilitated by rows of trunks flanked in longitudinal sense or bundles covered with ground and twigs. Where it is possible, it is preferable to have dirt and soil covered with turf, against snowfalls and frost. The advantage is a useful level ground to walk on comfortably and quickly, free from the snow in case of clear days. Along the slopes, in which the rock can offer at the same time foothold or slippery surfaces according to its geological composition and inclination, it is better to choose the side turned to East and South, sheltered from the icy winds and more exposed to the sun, which helps to keep it clear from the ice [10].

The parapets are built in the most dangerous places on the margins of the chasms or the cliffs. Between I and III century D.C., the incision of candy grooves $(0.20 \mathrm{~m}$ depth and 0.10 width, with a variable average distance from $0.80 \mathrm{~m}$ to $1.10 \mathrm{~m}$ up to $1.45 \mathrm{~m}$ ) is used. At higher altitudes, they indicate the points where the risks of skidding and falling in the void are high for wagons and animals.

In Trentino-Alto Adige, they are named Geleisestrassen ('track roads'; [10]). Instead, under Montefiascone (VT), in the Roman quarries of volcanic stone on the southern shore of the Lake of Bolsena, there are the tracks of a legendary Great wagon. This is a paretymological toponym because 
the original word is the 'crab' (vulg. Granciaro) and not the 'wagon', but these wagon tracks were really used to prevent the fall of the loads in water or the slipping towards the shore, where it was easier to sink.

Finally, along the Lazio coast from Fondi to Formia, grooves are found in the tract beyond Sperlonga with a wheelbase of $0.80 \mathrm{~m}$ in the steep segments of the so-called Via Flacca, a coastal branch of the Appia. Built by L. Valerio Flacco in 184 B.C., it crosses the Formianum Montem (Liv., XXXIX, 44, 6), affecting the cliff at a variable altitude of 30-40 $\mathrm{m}$, and has a transit step 3.8-4 m width in the most difficult passages, given by terraces in polygonal double curtain work and using the concrete to anchor them to the living rock $[15,16]$.

The cliffs can be arranged with cuts to have a regular surface and control the slope between 6 and $10 \%$. Preferably, there are short straight segments that exploit conoids at the top and interchange hairpins and harnesses (or 'livellette') with a variable inclination of $8-10 \%$ uphill and downhill [17]. The strongest gradients (over $9.5 \%$ and up to $20 \%$ on average) are on crossing places and are envisaged only in pedestrian and animal-walking routes [17]. There, the rock is engraved with transverse lines to give better grip to the animal paws, where it is necessary.

Finally, when the ground takes over, the erosive action of the runoff water is countered paving short stretches and using the technique of 'pontere', i.e., irregular stones vertically fixed in the surface and in parallel lines for a depth of $0.30 \mathrm{~m}$, like at the Scheggia (PG) pass for Via Flaminia. All together they make compact the level ground and facilitate its drainage [10].

\section{Materials and Methods}

\subsection{The Archaeological Approach}

Many records establish the range of possible ancient solutions used to overtake problems and obstacles in mountainous areas. Their importance also overcomes the epigraphical sources, sometimes absent or incomplete, and the archaeological data are not only a section of paved road, but also the complex interweaving of tangible and intangible elements (cultural traditions) that you find and understand applying all the Sciences of the Antiquity [6].

The first rule is about the itinerary sources. In an intermountain path, it is very easy to have changed the real distance of two stop-overs with another calculated like a straight line. In fact, if their topographic data (places, rivers, towns, villages, villa, hostels with their distance in roman miles from each other) are apparently not coherent with archaeological ruins, the explanation can be found in the criteria adopted to compose these sources when they speak of impervious geographic areas and unpredictable road path. Only at last can it be a problem of changes and revisions of their manuscripts during the medieval tradition.

Speaking about the obstacles, the slopes must be examined according to the road territorial context. In fact, in the mountains, a hindrance that slows down the circulation on the plains can become an expedient for elevating without too much effort. Furthermore, long "deviations" seemingly meaningless, are sometimes preferred to shortest and most "comfortable" (according to a modern perspective) routes, because in the period of reference it may have been more important to assist a place instead of another so "comfortable". Perhaps it has been a pure and simple speculation, or it has avoided an obstacle then disappeared after a lot of time. Maybe there was an administrative or political constraint, subsequently modified and no longer visible. There was also the intent to accentuate and enhance the approach to a place using a monumentalization. It leads to a preference for higher gradients so that the goal appears incumbent on the traveller, inspiring respect and veneration.

For example, in Tivoli (RM), this is the situation for the Clivus Tiburtinus; that is, the segment of Via Tiburtina near the city, in the Aniene narrow after the Ponte Lucano. Planned to exploit natural slopes varying between 6.7 and 12.6\% (current streets 'del Tartaro', 'degli Orti' in the intermediate section, 'del Colle' and 'di S. Valerio'), it is flanked and replaced between II and I century B.C. by an artificial path, shorter but more sloped (from 6.1 to 13.3 and 15.7\%) on a length of about $2 \mathrm{~km}$ (now 
street 'degli Orti'). It allows to enter and cross underground (by a via Tecta) the Sanctuary of Hercules, an architectural, cultic, and scenographic complex of primary importance for the city. Only between 340 and 350 A.D., with the suppression of the cult, the exaggerated slope of the clivus will be reduced in planitiem (CIL, XIV, 3582-3583) and also open to the transit of carts and wagons [18].

Another example is via Flacca between Fondi and Formia. It has a direct relationship with inland mountains, preferring to climb up (in Prato and Stazzo di Capratica and beyond the Grotta di S. Agostino) and lengthen the route (from Gegni to the sources 'di Vetere' and 'di Sept'acque'). It circumvents and excludes the flat areas, perhaps bogged or subject to be and requiring more expensive works also for the arrangement of a possible piedmont road, although shorter and direct [15].

Choices of opposite distinguish the sign of the branch of Flaminia to Pioraco (MC) along the valley of Potenza river. In this sector, we observe the evidence of a piedmont road, built cutting the rock at an altitude slightly higher than the modern S.P. 361, to avoid possible river floods [14].

Finally the archaeological documentation has provided important and valuable data to reconstruct the road layout. Milestones, necropolises, settlements, but also infrastructures such as bridges or viaducts, are testimonies placed in strong connection with the road works. In particular, the topographical relationship between villae and the Roman roads is often not specified in archaeological studies. It is very interesting and useful to understand not only the road track, but also its contact points with the territory.

\subsection{Geological and Geomorphological Analysis}

The main geological and geomorphological features of an area surrounding the inferred road path have been extracted in order to investigate how several factors, such as physiographic setting, specific landforms, and/or lithology outcrops can have influenced the planning of Via Herculia.

In order to verify a relation between stratigraphic features of rocks and deposits and their possible use as road pavement, the Mesozoic-Cenozoic rocks and Pliocene-Pleistocene clastic deposits have been grouped according to their main lithological and textural stratigraphical features. On this basis, a lithological map was derived using literature data (geological map of Italy at a 1:50,000 scale, Sheets: Potenza, Marsico Nuovo e Rionero in Vulture), together with a detailed geological field survey in key sectors of the study area.

The lithological map includes 14 units, defined also as a function of their similar lithotechnical characters and the potential susceptibility to erosion processes and slope instability.

In order to outline the main landform in the study area and their possible influence on the road path, a geomorphological analysis has been carried out by a detailed bibliographical research [19-27], field survey, and multi-temporal aerial photo-interpretation. This approach allows us to identify the main structural, fluvial, and slope landforms and investigate in a quantitative way their possible relationships with the selected road track.

Low-angle erosional and depositional surfaces, presence of alluvial plains, availability of deposits useful as road construction material, landslide processes, perennial water sources for water supply have been preliminarily identified as possible predisposing factors for the selection of the reconstructed path of the road.

Based on a GIS-supported preliminary analysis of the spatial distribution of these landforms with regard to the road track, we have quantitatively investigated the interaction between some of these possible control factors and the Roman road.

Then, topographic features and local gradient of the reconstructed road path have been extracted from a Digital Elevation Model (DEM) with a spatial resolution of $5 \mathrm{~m}$.

\section{Via Herculia: Description, Function, and Archaeological Evidence}

In Basilicata, a mountainous region located in southern Italy between the southeast belt of the Apennines and the junction of the Pollino massif, the first path of the Via Herculia, coming from Equum Tuticum (Masseria S. Eleuterio; Ariano Irpino, AV) in Irpinia to Summurano (Morano Calabro, CS) in 
Bruttii (Itin. Ant., 103.2-105.1), was built in the early III century A.D. with a segment from the ford on the river Ofanto (between Candela, AV, and Melfi, PZ) to Grumentum (Grumento Nova, PZ). About a century before the official recognition with the name Herculia, it highlights an additional issue with regard to the above-described problematic conditions.

It is a road conceived with economic function above all (transfer of agricultural produces from the lucanian areas of production to the markets of Italy Suburbicaria and Annonaria), and it joins the Appia in the $\mathrm{N}$ and the ab Regio ad Capuam in the S. As the already cited via Minucia and then Via Traiana, it is also arranged connecting older and pre-existing paths and was planned to take advantage of the morphology (sheltered sides, ridges and watersheds to climb up and follow the best natural background; rivers valleys and fords to penetrate the less accessible areas of the territory), reducing infrastructures (especially bridges) as far as possible.

The plan meets the policy of Severi emperors in the beginning of the III century A.D. They build new roads or restore pre-existences very damaged by an increasing of atmospheric phenomena (heavy rains, imbribus, and storms, adsiduis maris adluentibus fluctibus ad labem ruinam or adluvione maris, with consequent floods, rockslides, voragines, collapse of bridges and loss of tracks, as showed in AE 1893, 84; 1911, 101; CIL, III, 709 and 6939; VIII, 10304 and 10308; IX, 6010; X, 6811). According to Pliny (Plin., XXXVI, 125), the vias per montes excisas have marked the empire of Claudius (41-54 A.D.), with extensive use of cuts and galleries [28-30]. Now, the new paths take advantage of the morphology (ratio), supporting the scanning of miles by irremovable physical elements (hills, streams, rocky outcrops, and petrae, meaning 'mountains'), because they allow to restore the road after its disappearance.

The use of works (complanatis montibus et caesis rupibus ac dilatatis itineribus, in AE 1969/70, 607) is commensurate with the necessities. The first restorations, certainly following the codified legislation (D. XLIII, 11.1-3), are made in 311 A.D. by emperor Maxentius. He restores it (pristinam faciem; CIL, IX, 6058-6059, 6066-6067 = 6963-6964, 6971-6972) and gives it the name Herculia in memory and honor of his father and predecessor, Maximianus Herculius (286-305). In order to facilitate the traffic of wagons and, in general, to ensure greater surveillance on the road, the interval between one stop-over and the next is reduced to an average of 12 miles, in open places and mountain sections [6].

In this period, at the beginning of IV century A.D., rustic villas join agricultural productions (viticulture, olive and cereal growing, breeding of pork, doliare craftsmanship, wool production, and the exploitation of larger wooded areas than today) with marketing and sales, useful for sustenance not only of the family group, but also to sell products in the great markets of the Empire. Then, they must necessarily be organized in close relation with the road system.

Therefore, they are collateral indicators of the passage of an ancient road. Following the Via Herculia from Ofanto river and Melfi countryside to Grumento Nova (Figure 2), 126 roman miles after, we observe archaeological evidences of 24 villas along the reconstructed path of the road (a detailed description of the archaeological record is reported in the Appendix A whereas Appendix B summarized a list of the bibliographic sources). They are within a maximum range of 1.5 miles from the Via and have continuity of life up to VII century A.D., although their density has reduced during the III. The first villa is probably the statio of Beleianum in Serra dei Canonici (record number, $\mathrm{nr} 4$, Appendix A), just $300 \mathrm{~m}$ to the NE of XVI milestone.

In Lavello, some structures (Lamia di Turi, Piani di Scaccia, Masseria Chiengo, Sterpare, nr. 5, 6, 8, 9, Appendix A), located a short distance from the Tratturo Regio Melfi-Castellaneta that there will take over the Via Herculia, have given many important finds of the pars rustica (dolia, trachyte millstones, opus spicatum floors).

Near Venosa, some ruins identified in the Piano Regio (nr. 10 and 11, Appendix A) are close to the road network, and Toppo di Costanza (nr. 12, Appendix A), on the top and along the northern slope of the hill which overlooks the Vallone Contista, has the remains of a villa with rustic and residential sectors spread out in a larger area. Instead, the villa of Magnone (nr. 16, Appendix A), in the countryside of Atella town, has only productive parts with many pithoi defossa (jars and pits for storage). 

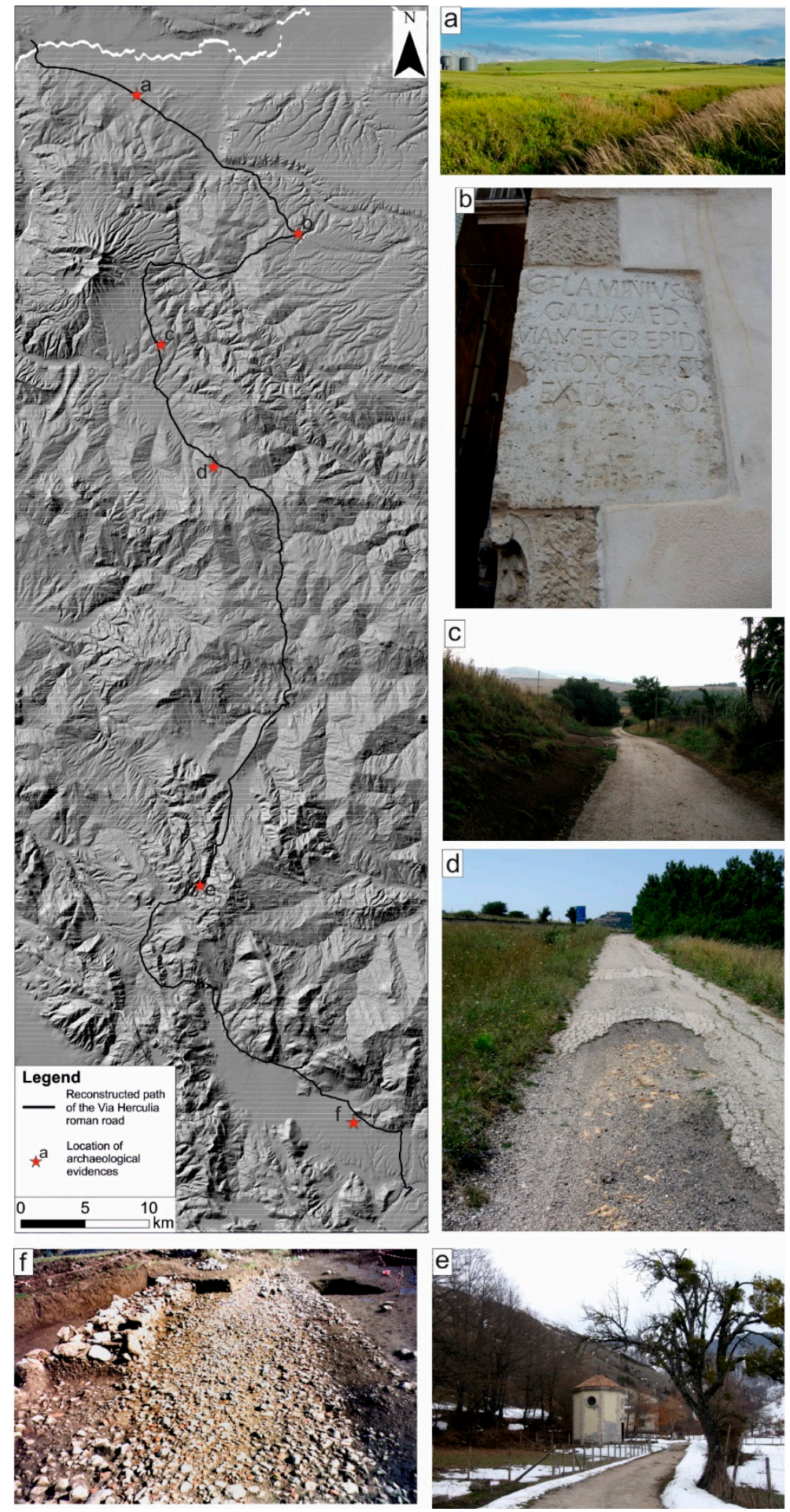

Figure 2. (a) The Herculia at the ford of Vallone di Catapane (XII milestone from Venosa), near the stop-over of Beleianum (villa in Serra dei Canonici; Melfi, PZ). (b) The remaking of an important road of ager Venusinus in the Flaminius Gallus onorary epigraph (CIL, IX, 442; Venosa, PZ). (c) The Herculia in the Braida pass, one milestone before the stop-over of Pisandes (villa of Torre degli Embrici) and 23 miles from the Ofanto's ford. The cobblestones are visible under the asphalt on its left side. (d) The road coming from Castel Lagopesole (Avigliano, PZ), VIII milestone from Pisandes near the stop-overs of ad fluvium Bradanum (and then Lucos). (e) The road in the pass of Monte Arioso near the S. Michele church (Sasso di Castalda, PZ), XIII milestone from Potentia (Potenza). (f) Probably the road near the villa of Porcili, 10 miles from the stop-over of Acidios, now Fonte S. Giovanni near Marsico Nuovo (Potenza). 
The large villa of Torre degli Embrici, in S of Rionero in Vulture (nr. 17, Appendix A), has four construction phases beginning in the II century B.C. and in the IV A.D. (i.e., the statio of Pisandes).

Some miles around Potenza, a rich villa with colored mosaics in the reception hall and the apsidal space, can be observed in Malvaccaro locality (nr. 18), whereas another one strictly related to the ancient road is located in a strategic position of the countryside of Pignola town (i.e., Le Tegole locality, nr. 21, Appendix A). Finally, there are two imperial properties in Barricelle (Marsicovetere) (nr. 22) and in Maiorano (Viggiano) (nr. 24), located along one of the connecting roads between the Valle del Basento and the Val d'Agri [31-33].

\section{The First Test-Segment from Filiano to Sasso di Castalda}

\subsection{Geological and Geomorphological Setting of the Study Area}

The study area (Figure 1) extends for $46 \mathrm{~km}$ along a N-S direction transversal to the axis of the southern Apennines from the axial belt of the chain to the northern areas of the Bradano foredeep areas to the north [34,35]. Southernmost sectors of the area cut the tectonically-controlled intermountain depression of the High Valley of the Agri River, whereas the Roman road crossed to the north the morphostructural ridges with steep slopes of tectonic origin (i.e., fault and fault-line scarps) of the axial zone of the chain. Northernmost sectors of the study area are featured by the morphostructures of the frontal sector of fold-and-thrust belt and low-relief areas of the Bradano foredeep [36-38].

From a geological point of view, the study area is mainly characterized by strongly deformed geological units of the Lagonegro basin and flysch deposits of Miocene syntectonic basins [37,38]. Middle Triassic-to-Miocene Lagonegro units are characterized by shallow-water, basinal, and shelf-margin facies and limestone and siliciclastic deposits of pelagic environment, affected by dome-and-basin folds [37]. Middle Cretaceous to Oligocene grey and reddish clays and marls (Argille Varicolori and Corleto Perticara Fms), and upper Oligocene to lower Miocene marls and volcaniclastic sandstones (Tufiti di Tusa Fm), also outcrop widely in the study area. The upper Miocene deposits are mainly constituted by deep-sea conglomerates, sandstones, and pelites (Gorgoglione Flysch Fm.), unconformably overlying on the Lagonegro units [37]. Thick Pliocene to Pleistocene clastic succession made by marine to continental clay, sandstone and conglomerate, and Quaternary continental deposits represent the youngest deposits of the study area [22,34,39].

The highest peaks and the summit of the belt are frequently characterized by remnants of ancient erosional land-surface, which represents the geomorphological relict of old morphoevolutionary stages of long-term erosion and polygenetic planation processes [40]. These landforms can be mainly observed in the southernmost sectors of the study area (i.e., the axial zone of the chain, see [40]). In this sector, regional uplift, Quaternary faulting, and base-level lowering promoted the development of several orders of low-angle erosional surfaces, which are arranged in a staircase geometry between 500 and $1500 \mathrm{~m}$ a.s.l. above the present-day thalwegs ([22] and references therein, see also Figure 3). Basin-border faults are also responsible for the genesis of many Quaternary basins, such as the High Agri River valley or the Melandro River basin, which are mainly filled by Quaternary lacustrine and alluvial deposits and crossed by longitudinal V-shaped valleys with thalwegs generally between 500 and $700 \mathrm{~m}$ a.s.1. [22]. The outer zone and the front of the chain are featured by NW-SE-trending morpho-structural ridges and thrust sheets, which are mainly carved in Cretaceous-to-Miocene pelagic deposits and Pliocene clastics related to the development of satellite basins [27,37,39,41,42]. Medium- to high-relief and the outcrop of poly-deformed and clay-rich lithological complexes represent the main control factors controlling the development and the evolution of deep landslides [20,21]. The landscape exhibits a gentler topography in the Bradano foredeep areas and Ofanto basin (Figure 3), which are filled by marine-to-continental Pliocene-Quaternary clastic sediments [27,35]. Main landslide types of this sector are earth flows and shallow slope failures $[17,27]$. 

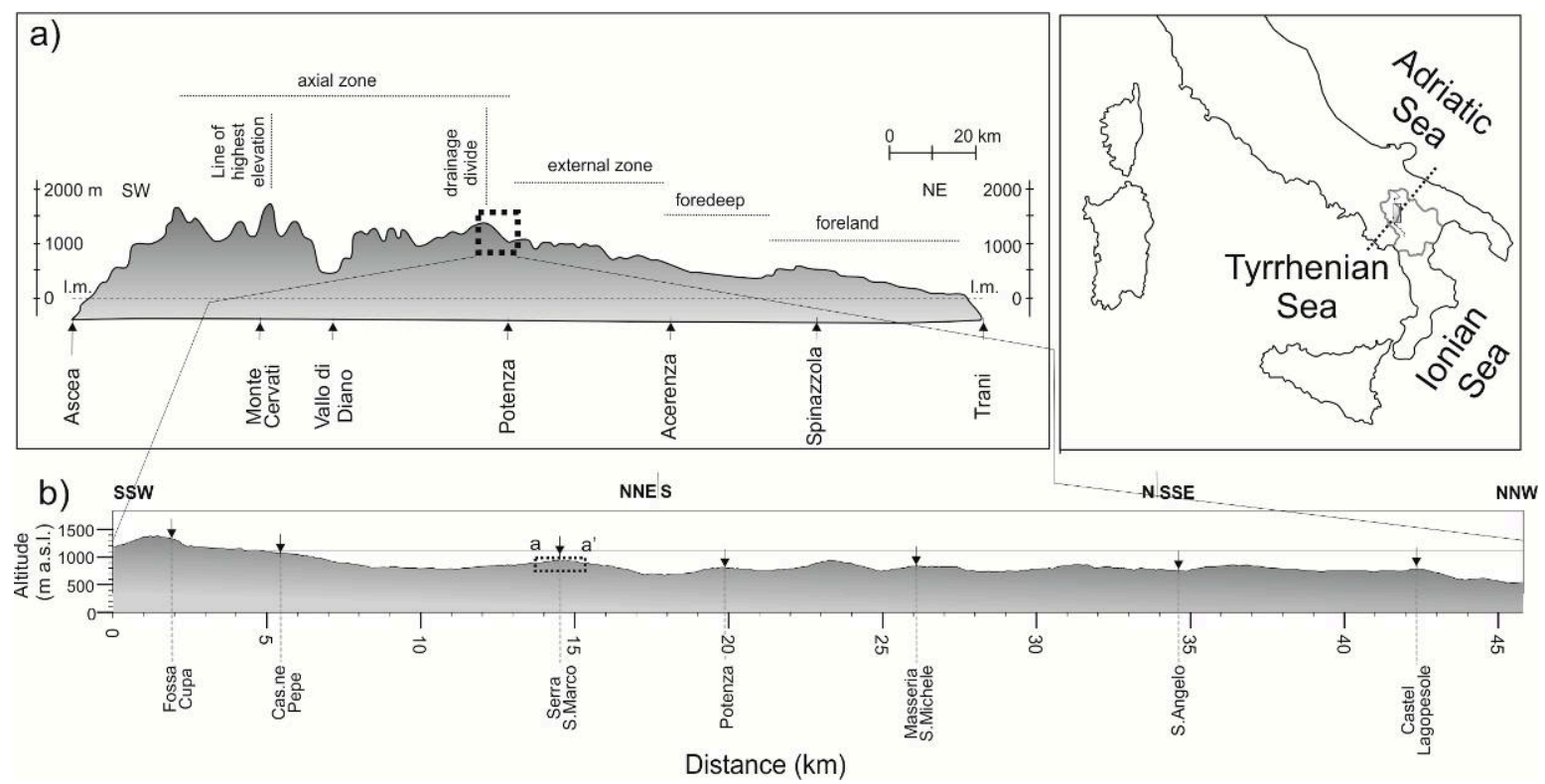

Figure 3. (a) Main morphostructural domains crossed along an Apennine transept passing through the study area. (b) Topographic profile of the Via Herculia from Sasso di Castalda to Filiano. The dashed box a-a' indicates the sector of Serra San Marco high, where the roman road crossed a low-angle erosional surface.

\subsection{Lithological Map}

Landscape of the southernmost sectors of the study area is carved by Meso-Cenozoic rocks of the Lagonegro basin. The lower stratigraphic part of the succession is composed by lower-middle Triassic shallow-water siliciclastic sediments, organogenic limestones, and, towards the top, siliciclastic basinal deposits (Monte Facito Fm), which passed to upper Triassic cherty limestones (Calcari con Selce Fm).

Jurassic deposits are represented by radiolarites and cherts, covered by lower-middle Cretaceous turbidite succession of the Galestri Fm (siliceous marls and shales). Toward the top, upper Cretaceous to Oligocenereddish marls and shales with intercalations of calcareous-clastic sediments ('Flysch Rosso' Fm) occurred. To the north of the Lago del Pantano lacustrine basin, the study area is featured by Pliocene piggy-back deposits of the Potenza basin. The sedimentation is represented by a 300-m-thick succession of grey silty clays with rare shell fragments, interbedded with marine fine sands and marine/transitional gravels. This succession unconformably overlies the deformed pre-Pliocene bedrock, mainly composed by varicolored clays and marls (Argille Varicolori Fm). The northernmost sectors of the area are featured by clays and marls of the Argille Varicolori Fm and Upper Oligocene to Lower Miocene syntectonic volcaniclastic, siliciclastic and calciclastic deposits of the Paola Doce Fm. and quartzarenite of the Numidian Flysch.

In order to verify which were the main lithologies affected by the passage of the Via Herculia and useful for road construction, a lithological map (Figure 4) was built, starting from the basic geological data. After the description of lithological units, the possible use in one of the three main layers of the Roman roads has also been indicated: (1) a base layer (statumen), consisting of stones and compacted clay, filling a pit at least $60 \mathrm{~cm}$ deep; (2) an intermediate layer (Rudus), consisting of stones, sand, and lime mixture; and (3) a shallow layer (Nucleus), consisting of crushed stone and gravel.

In particular, the units considered are the following:

- Anthropic landfill (rip, Figures 4 and 5), municipal, and quarry waste dumps. Thickness up to $10 \mathrm{~m}$.

- Accumulations of landslides and colluvial deposits (fra). The current and ancient landslide deposits were considered as a separate group. As part of the colluvial deposits, pedogenized and loose debris, from gravel to clayey, have been added, depending on the original succession 
involved by gravitational movements. The deposit is mixed with sands and blackish-brown silts with small reworked and pedogenized calcareous pebbles, marl and arenaceous, of colluvial origin. These deposits are the fillings of paleochannels and/or little valleys along the slopes, and at the edges of active landslides, representing the accumulations of ancient landslides. The thickness varies considerably, up to about $10 \mathrm{~m}$.

- Loose and thickened alluvial deposits and fluvio-lacustrine deposits (at). This group of deposits has been referred to as pebble floods, current, recent and terraced, fluvial-lacustrine deposits, gravels and sandy gravels with sand and silt lenses, deposits of inactive and incised torrent fans and floodplain deposits. The thicknesses reach up to some tens of meters (deposits useful for Nucleus).

- Loose and thickened colluvial deposits (dc). Current and recent sandy-silt colluvial deposits have been reported to this group locally mixed also with eluvial products. These deposits are easily eroded and the stability depends on the stratigraphic relationships (deposits useful for Rudus).

- Loose slope deposits, locally from thickened to slightly cemented (dv). This group includes slope debris, gravel-conglomerate levels interbedded with sandy sediments and uncemented slope breccias, and has a different lithotechnical behavior and water content than the overlapping soils. The thickness reaches up to 5-10 $\mathrm{m}$ in lens or localized layers (deposits useful for Nucleus and Rudus).

- Lacustrine sediments from recently to medium thickened (lac). These are silt and whitish sands with gravel lenses, clayey, clayey-marly, and clayey-sandy deposits not over-consolidated, sometimes with intercalated levels or lignite banks. They have a high degree of erodibility and are affected by both shallow and deep landslides (deposits useful for statumen).

- Clayey, silty-clay, and clay-sandy sediments, plastic, massive or stratified clays (ag). They are often affected by widespread phenomena of erosion accentuated up to badlands type phenomena (deposits useful for statumen).

- Well-assembled conglomerates and breccias, irregularly stratified, cemented debris, cemented dejection cones (cbd) in a sandy-silty matrix sometimes prevalent of reddish and yellowish color. This unit includes slope debris and cemented debris (middle Pliocene and upper Pliocene-middle Pleistocene), as well as the reddish earthy of recent deposits. The breccias are cemented to calcareous and calcareous-dolomitic elements in layers and benches more or less distinct, with intercalation of paleosoils (deposits useful for Nucleus and Rudus).

- Sands that are well thickened, massive, locally cemented, in layers and in banks, with few marly and clay intercalations associated with conglomerates in slow or in layers (sab). This group includes sand and sandstones in layers and banks with levels of microconglomerates, bioclastic arenites, and little cemented yellowish calcarenites. They are represented by the basal and top terms of the lower Pliocene cycle succession of the Pliocene satellite basins and by Miocene deposits of the Serra Palazzo formation (deposits useful for Rudus).

- Stratified or massive conglomerates and well cemented sandstones (cg). It includes the arenaceous and conglomerate levels of the Flysch of Gorgoglione and of the quartzarenites of the Numidic Flysch (deposits useful for statumen).

- Limestone stratified in bedded medium or thin layers, sometimes with marly and clay interbeds, and with flints in slow or nodules (Cal). Mainly, the well stratified carbonatic terms of the Mesozoic basin sequences of the Lagonegro basin succession are included, in addition to the calcarenitic-calciruditic alternations of Oligocene-Miocene age (deposits useful for statumen).

- Compact or thinly layered siliceous rocks (ss). The group includes the alternation of shales, jaspers, and radiolarites with intercalations of calcilutites, clayey marls, and sicilized shales of the Mesozoic basin basins of the Flysch Rosso, of the Flysch Galestrino and Scisti Silicei (deposits useful for statumen). 
- Heterogeneous complex with a prevalence of the stone component (clap). Some calcarenitic-marl-arenaceous formations of the Mesozoic sequences of carbonate platform and calcarenitic-marly terrestrial basinal sequences have been assimilated to this group. In particular, part of the formations of Corleto Perticara, Albidona, and Member Sant'Arcangelo were included (deposits useful for statumen).

- Heterogeneous complex with a prevalence of the clay component (cag). The terms with a predominantly clay component of the aforementioned formations, as well as the clayey terms of the Varicolor Clays, have been assimilated to this group (deposits useful for statumen).

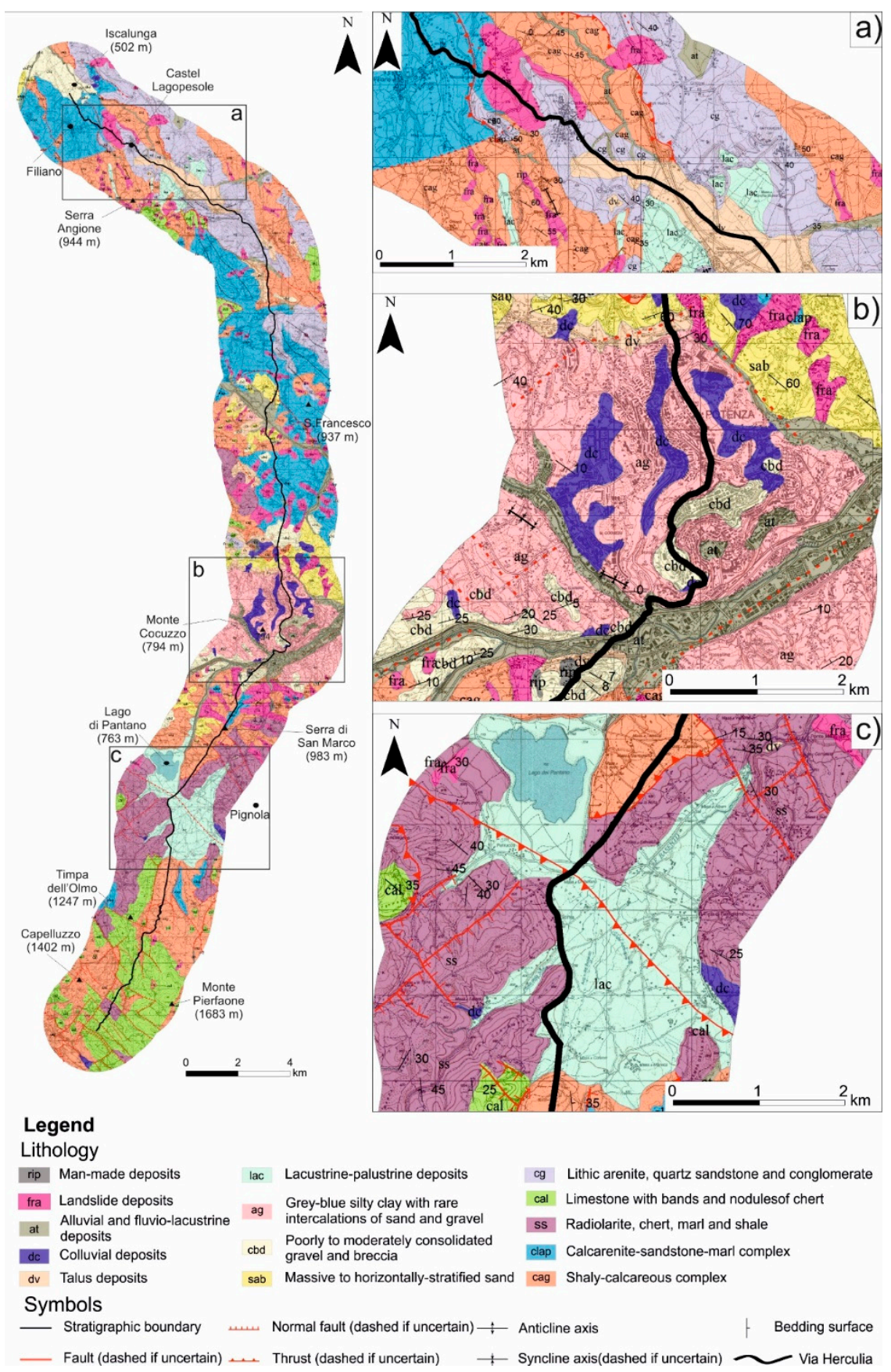

Figure 4. Geolithological maps of the sample test-site and detailed sketches of several segments of the Herculia roman road $(\mathbf{a}, \mathbf{b}, \mathbf{c})$. 


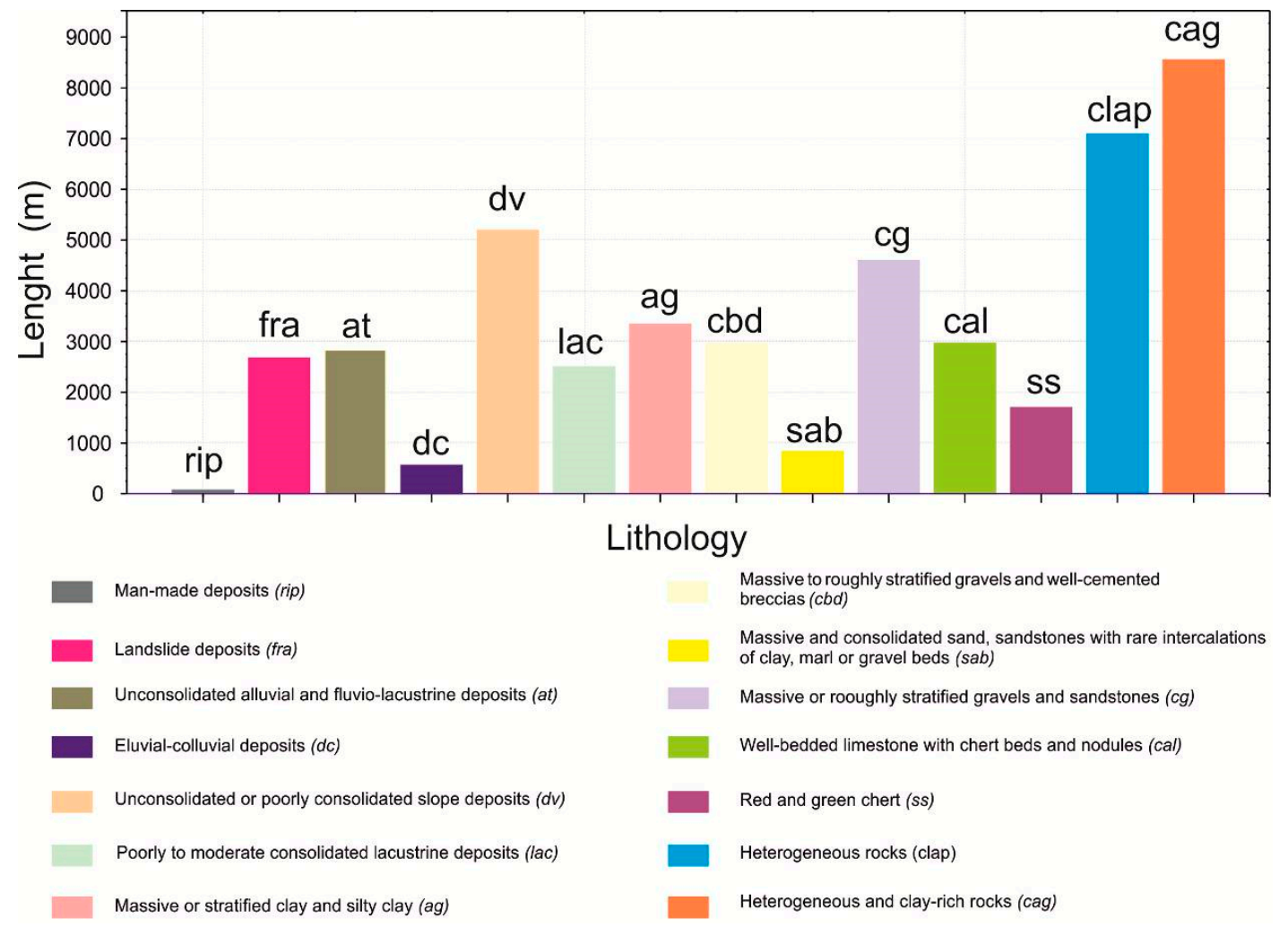

Figure 5. Histogram showing the cumulative length distribution of the segment of the Via Herculia for the different lithological units of the study area. Please note that the relative maxima of the diagram are represented by heterogeneous lithological classes (see text for explanation).

From a lithological point of view (Figure 4), the Via Herculia mainly crossed an area featured by terrigenous rocks of the heterogeneous complex with a prevalence of the clay and stone component (cag and clap, Figure 4) and unconsolidated slope and colluvial deposits (cg and dc, Figure 4).

In summary, the percentage of possible use of the single lithological units that intersect the Roman consular road can be summarized as follows:

1. Nucleus $20 \%$ (lithological units at, $\mathrm{dv}, \mathrm{cbd}$ );

2. Rudus $20 \%$ (lithological units dc, dv, cdb, sab; and

3. Statumen $60 \%$ (lithological units lac, ag, cg, cal, ss, clap, cag).

Visual inspection of the lithologic map (Figure 4) and quantitative analysis of the different lithological units (Figure 5) allowed us to appreciate how the Via Herculia crossed sectors characterized by loose or poorly-cemented sandy-conglomerate, or alluvial deposits, which could constitute an immediate source of incoherent material for the construction of the pavement.

\subsection{Geomorphological Map}

The morphostructural evolution of the southern Apennines is characterized by stages of tectonic uplift and fault activity, alternated with periods in which sculpture of erosional surfaces and deposition of sedimentary bodies took place in several intermountain basins. Both flat land surfaces and the tops of the alluvial deposits are related to the different past base levels and are distributed at altitudes ranging from 500 to $1500 \mathrm{~m}$ a.s.l (Figure 3).

A detailed geomorphological field survey and mapping have been carried out in order to derive the main fluvial, structural, and slope landforms of the study area, which have been summarized in a geomorphological map (Figure 6). 
Large sectors of the investigated landscape are deeply cut by a drainage network, characterized by a dominance of V-shaped valleys where erosional processes are dominant with respect to the depositional ones. Accordingly, the occurrence of alluvial plain in these narrow thalwegs is rare. Southernmost sectors of the study area are featured by impressive carbonate ridges and steep slopes of tectonic origin. The landscape of the central and northern sectors are mainly characterized by outcrops of terrigenous and clastic deposits and, consequently, it is dominated by both gentle slopes and affected by widespread mass-movement processes.

Although this sector is featured by widespread landslide phenomena, the path of the road was mainly developed in the lower-altitude sectors of the slopes, with limited interaction between the road path and mass movement processes. A paradigmatic example is shown in Figure $6 c$, where it is possible to appreciate how the road tends to avoid landslide slopes, developing along the crest of the low-angle erosion surface of Serra San Marco.

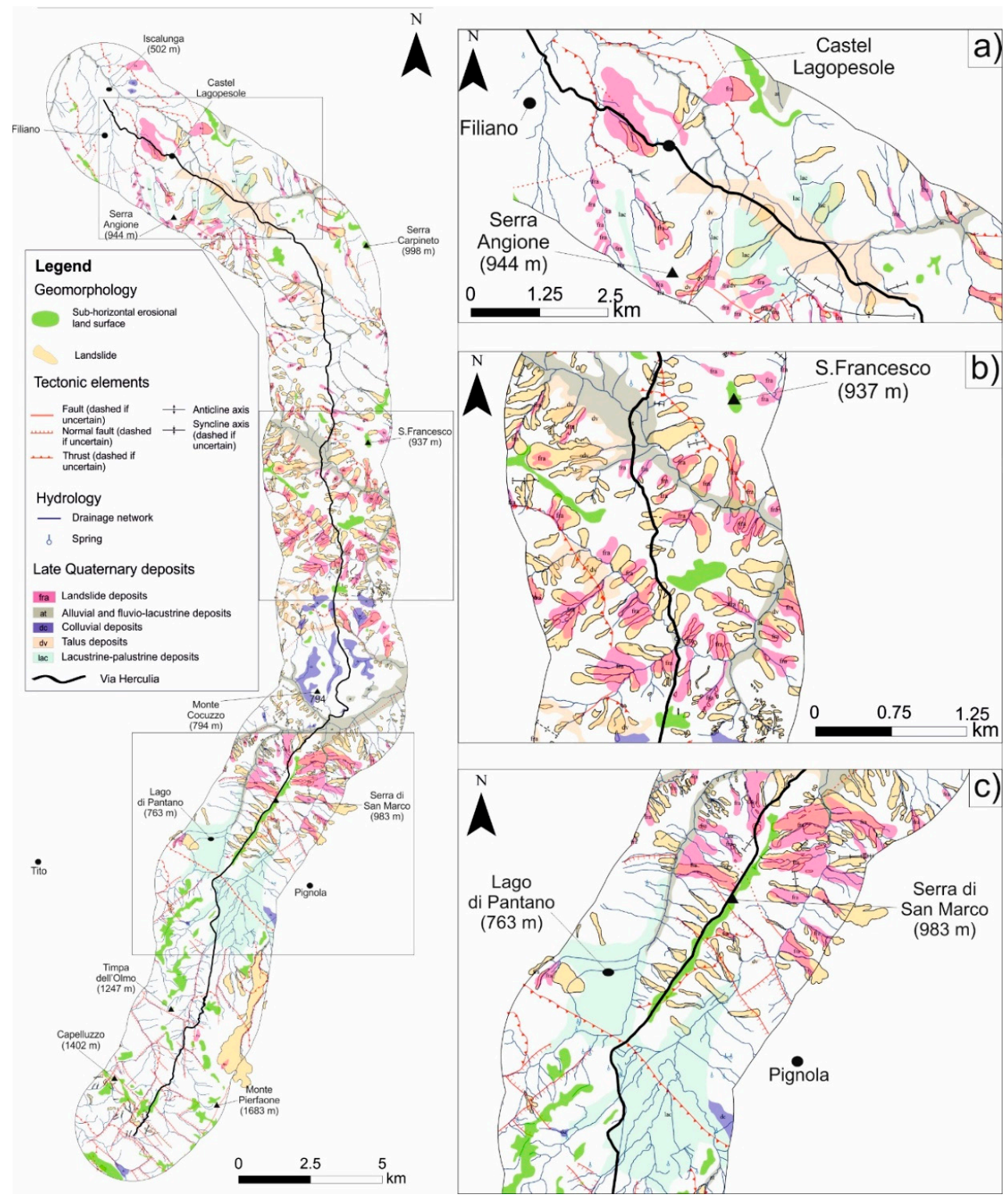

Figure 6. Geomorphological map of the study sector. Detailed maps (frames (a), (b) and (c)) show some key sectors of the study area, where the path of the Via Herculia appears to be controlled by the spatial distribution of several geomorphological elements (see text for further explanation). 
Low-relief topography, the presence of alluvial plains, the absence of landslide processes, and the presence of perennial water sources for water supply have been preliminarily identified as possible predisposing factors for the selection of the reconstructed path of the road.

The Via shows an overall variation of the height between 518 and $1388 \mathrm{~m}$ s.l.m., an average height of $837 \mathrm{~m}$ s.l.m. and a multimodal distribution. The frequency distribution of the road altitude classes shows a very dispersed main mode at height between 730 and $850 \mathrm{~m}$ s.l.m, and several minor peaks with a high degree of dispersion at altitudes between 880 and $930 \mathrm{~m} \mathrm{~s} .1 . \mathrm{m}$. and 670 and $700 \mathrm{~m}$ s.l.m. (Figure 7). Further minor classes can be observed in the altimetric ranges $1000-1125 \mathrm{~m}$ s.l.m., 1150-1200 m s.l.m., 520-535 m s.l.m., and 575-605 m s.l.m. In particular, it is possible to observe as local segments of the path developed close to the low-relief erosional land-surfaces (for example, along the Serra S. Marco ridge, Figures 4 and 6) or along the depositional surfaces, located in correspondence to the poorly-incised alluvial plain of the Piano del Conte and Pantano di Pignola areas.
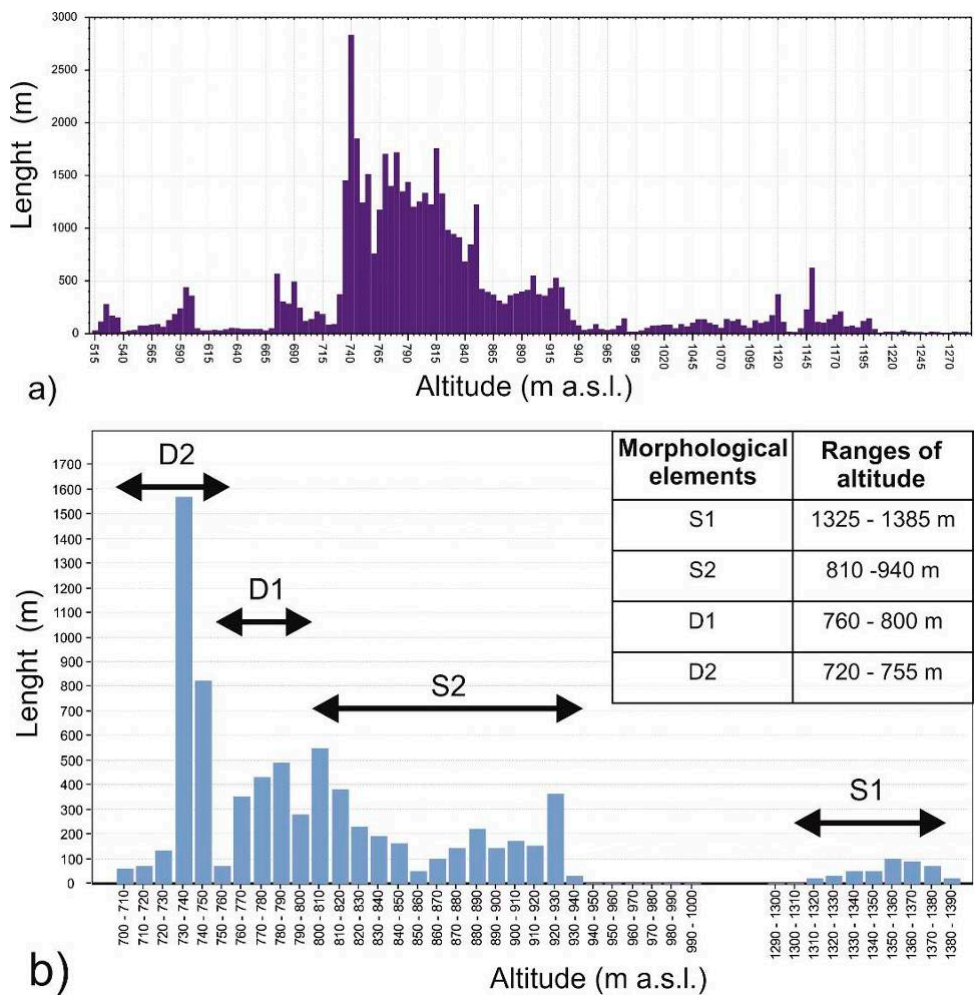

Figure 7. Histogram representing the frequency distribution of altitudes of the whole path (a) and only for the tracts of the path that intercept low-angle erosional and depositional morphological surfaces (b).

The comparison between the height classes shown in Figure 8 and the low-angle erosional surfaces detected in the study area, partly coinciding with morphological elements of regional and sub-regional significance of the southern Apennine chain [22,40], highlights how a significant part of the sample sector of the Via Herculia (about 5 of the $46 \mathrm{~km}$ ) interacts with these morphological elements of the South Apennine chain landscape. 


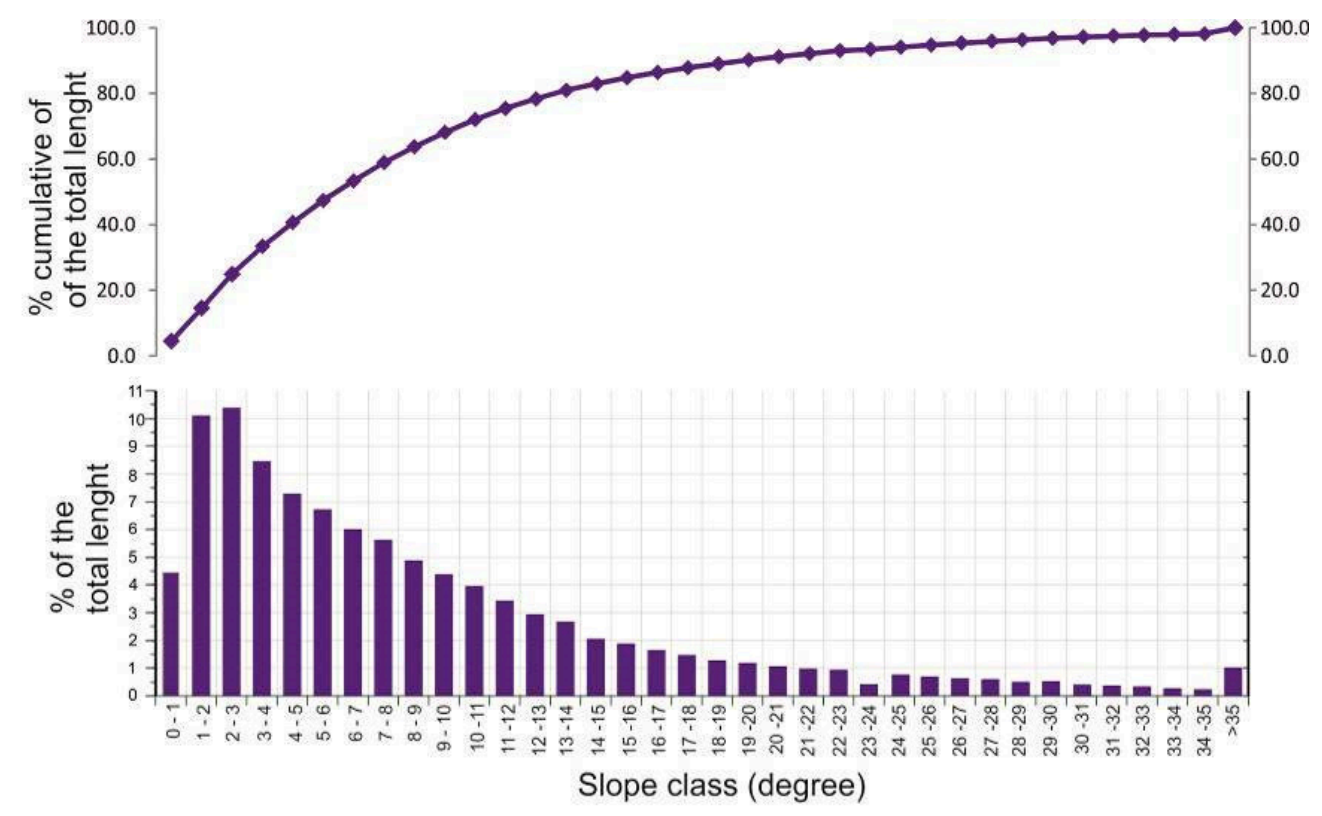

Figure 8. Frequency distribution (to the bottom) and cumulative curve (to the top) of the slope classes of the reconstructed path of the Via Herculia.

From the analysis of the local gradient detected along the path examined (Figures 8 and 9), it can be seen how a large part of the same (about $44.7 \mathrm{~km}$ ) occurs in the main slope class ranging from $3^{\circ}(5 \%)$ to $15^{\circ}(26 \%)$. Such moderate slopes are developed mostly along axes of elongation of summit low-angle paleosurfaces (Serra San Marco) or valley floor (Piano del Conte, Pantano, Basento valley) and cut rocks and deposits suitable for the road pavement construction, without necessity to carry out excavations for trench sections or to walk along slopes halfway, interacting, only in part, with landslides occurring along the clayey-marly slopes.

Higher slope classes are linked to the connection points between the valley floor and the summit flat parts, or where the stone lithology imposed steeper sections that probably were not practised by carts, but only by pack animals ([43], see the examples of Clivus Tiburtinus, Via Flacca and Flaminia in paragraph 3.1). 


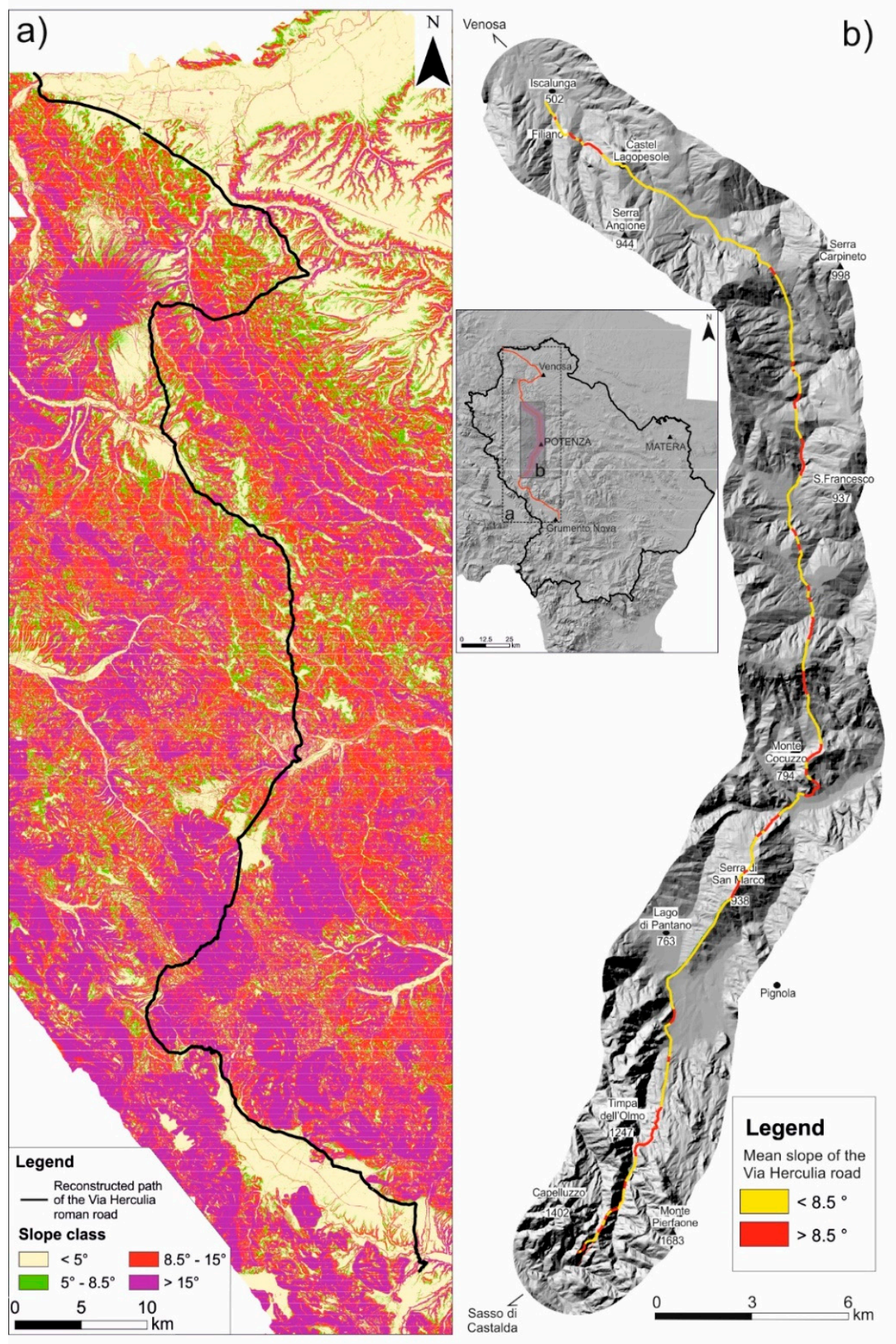

Figure 9. (a) Slope map of the study area; (b) hillshade of the study area and mean slope of the Via Herculia.

\section{The Second Test Segment: The Upper Agri River Valley}

Analysis of the archaeological record in the Upper Agri river valley provides controversial evidences and constraints on the reconstruction of the Via Herculia path. Indeed, the archaeological analysis has suggested four possible road paths (same distance of 10 roman miles, Figure 10). 


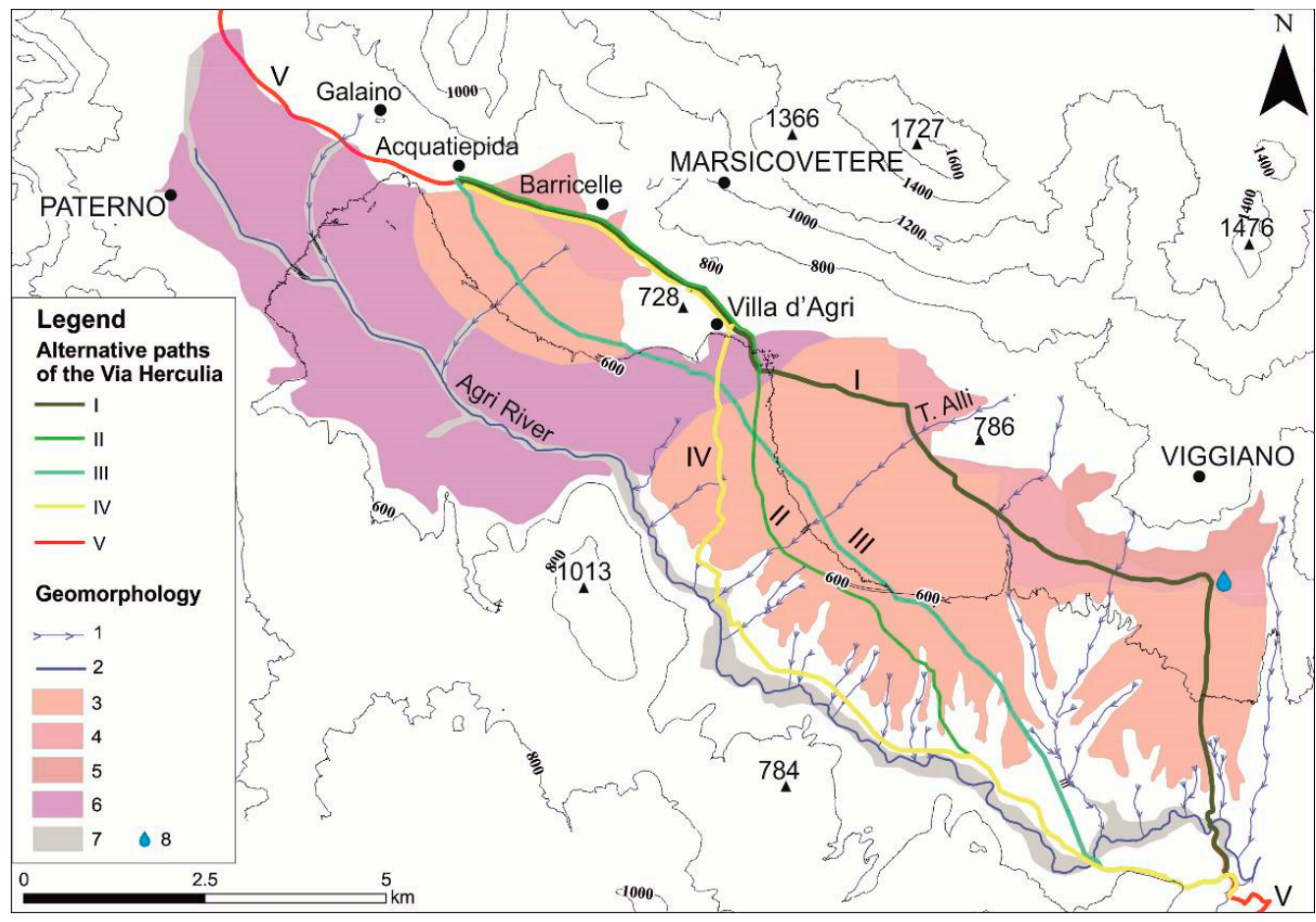

Figure 10. (I) First hypothesis; (II) second hypothesis; (III) third hypothesis; (IV) fourth hypothesis; (V) Via Herculia track. (1) Channel incision; (2) main river (Agri River); (3) first generation of alluvial fan; (4) second generation of alluvial fan; (5) third generation of alluvial fan; (6) fluvial deposits (first generation); (7) Late Quaternary floodplain deposits; (8) Fonte San Giovanni spring. Geological and geomorphological features are partly derived by [44].

Three of them connect the site of Villa d'Agri with Grumentum, whereas the others connect the site of Acquatiepida (1.5 km Est of Galaino) to the Grumentum. From a geological and geomorphological viewpoint, the four paths show similar lithological [44] and slope features. The analyzed sector is characterized by alluvial fans and fluvial deposits, referable to $a t$ and $d b$ lithological units, and by a road slope $<8.5^{\circ}$. We infer that the alluvial and flooding processes related to the Agri river can represent the main control factor in the selection of the ancient path. The IV hypothesis (Figure 10) is located very close to the Agri riverbed, and therefore it was probably more exposed to possible phases of flooding and consequent erosion of the pavement; the tracks II and III are characterized by at least three intersections with the Alli river and minor streams, which deeply dissect the ancient tops of alluvial fan during the Holocene. Also in this sector, geomorphological analysis suggests a possible occurrence of relevant flooding processes. The hypothesis I crosses the proximal area of the alluvial fans and the comparison with the others hypotheses indicates a lower height of the fluvial scarps and a low degree of the intensity of flooding phenomena. Finally, this road path passes near an important historical point of water supply (i.e., the Fonte S. Giovanni spring).

\section{Final Remarks}

The geomorphological and archaeological studies were conducted in a first phase independently and, subsequently, the data and route proposals were compared.

The quantitative geological, geomorphological, and hydrological observations on the track of the Via Herculia have been confirmed by literature data, as in the case of the slope threshold of the viability of chariot or pack animals, and in its geographical delineation. In relation to this last point, in fact, geomorphological analysis suggests that the reconstructed path of the Via Herculia develops for a large sector along the axes of low-angle erosional surfaces or valley floors and in areas not affected by the 
phenomena of landslide and accelerated erosion, although these phenomena are widespread in the study area (Figure 6).

By integrating all these considerations, we came to the definition of a final proposal of the studied route (Figure 11), which took into account the archaeological, geomorphological, and hydrographic constraints, respecting the distances set by the itinerary sources. The implemented methodology can represent a concrete example of integration between geological and archaeological data applied to the definition and understanding of problems related to strategic aspects of design and construction of important past road junctions (see also [45]).

The integrated analysis of such data in a similar multidisciplinary perspective has allowed, without predefined conditions, to define a more complete picture of the planning and realization of the Roman road system in Basilicata, taking into account numerous aspects often overlooked in similar studies.

The geological and archaeological realities have a weight even to, if not higher than, any model or preconceived hypothesis about the composition, evolution, and organization of a road. A valley does not necessarily pledge the preservation of an ancient road, if there are active slope processes and fluvial dynamics (see for example the "disappearance" of the Via Annia in the Vallo di Diano, between Polla and Casalbuono (SA), and its "reappearance" in the next segment crossing the mountains [46]).

In a complex landscape, the geological and geomorphological processes and features can change, even at a short temporal and spatial scale.

The adopted solutions can be repeated but there are no codifiable rules, not even about the type of paving used. It is up to the researcher to understand the situations and to use the case studies known to hypothesize choices made in ancient times and possible solutions adopted to search their remains and identify also the most evanescent.

So it happens that generally, when the orography is strongly characterized, and therefore the constraints propose reduced alternatives of interpretation, the difficulties of reading are not excessive, at least in theory. But when the road network is involved in the creation of macrostructures, so it becomes negligible to change the alignment of a road sector, the things get enormously complicated [18]. 


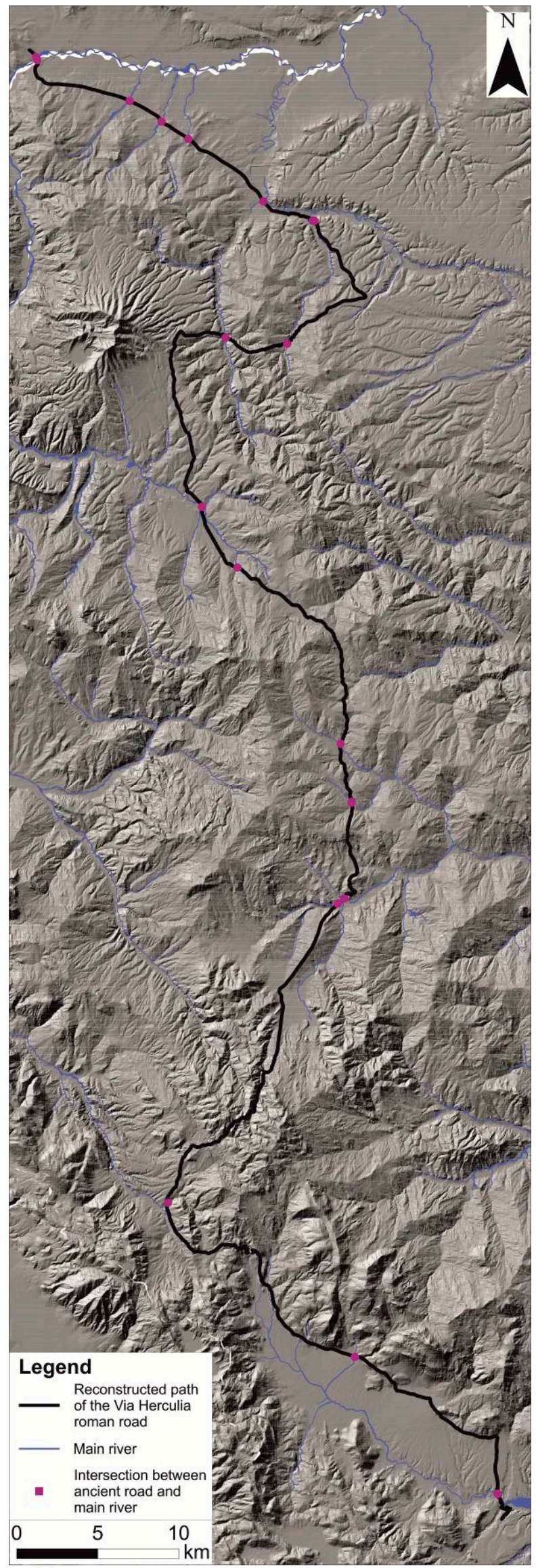

Figure 11. Topographic map of the final proposed route of the Via Herculia in Basilicata and interaction between the road and drainage network. 
Author Contributions: Conceptualization, M.L., S.D., and D.G.; methodology, M.L., S.D., and D.G.; software D.G.; geomorphological analysis, M.L. and D.G.; formal analysis, M.L. and D.G.; archeological investigation, S.D.; appendix, A.S.; resources, M.L.; data curation, M.L., S.D., and D.G.; writing-original draft preparation, M.L., S.D., D.G., and A.S.; writing—review and editing, M.L., S.D., and D.G.; supervision, M.L. and S.D.; project administration, M.L.; funding acquisition M.L.

Funding: This research received no external funding.

Conflicts of Interest: The authors declare no conflict of interest.

\section{Abbreviations}

$\begin{array}{ll}\text { AISCOM } & \text { Associazione Italiana per lo Studio e la Conservazione del Mosaico } \\ \text { APPZ } & \text { Archivio Sorico della Provincia di Potenza } \\ \text { Atti Taranto } & \text { Atti del Convegno di Studi sulla Magna Grecia } \\ \text { BollStoBas } & \text { Bollettino Storico della Basilicata } \\ \text { BSR } & \text { British School at Rome } \\ \text { BTCG } & \text { Bibliografia Topografica della Colonizzazione greca in Italia e nelle Isole tirreniche } \\ \text { NSc } & \text { Notizie degli Scavi di Antichità } \\ \text { SEBarc } & \text { Sylloge Epigraphica Barcinonensis } \\ \text { Temporis Signa } & \text { Archeologia della tarda antichità e del medioevo }\end{array}$




\section{Appendix A. Archaeological Evidences of Villas Along the Reconstructed Road Path}

\begin{tabular}{|c|c|c|c|c|c|c|}
\hline Villa & Position & Site & Municipality & Description & Cronology & References \\
\hline 1 & $\begin{array}{l}9.5 \mathrm{~km} \mathrm{NW} \text { of Melfi, and XVI miliarium } \\
\text { of Herculia, from Venosa to Ofanto river. }\end{array}$ & $\begin{array}{c}\text { LeONESSa } \\
\text { CONTRADA Tesoro }\end{array}$ & Melfi & $\begin{array}{l}\text { Pars rustica of a villa with torcularium (I-III } \\
\text { century A.D.) with walls relating to the most } \\
\text { ancient phase in opus reticulatum and floors in } \\
\text { opus spicatum. The villa was reused in Late } \\
\text { antiquity as a church. }\end{array}$ & $\begin{array}{l}\text { Late Republican-Early } \\
\text { Imperial and Late } \\
\text { Antiquity }\end{array}$ & $\begin{array}{l}\text { Adamesteanu 1974, pp. 228-229; } \\
\text { Klein Andreau 1980, pp. 345-356; } \\
\text { Salvatore 1984, pp. 30-31; Volpe } \\
\text { 1990, p. 57; pp. 142-144, n. 241; } \\
\quad \text { Tagliente 1991, p. 539. }\end{array}$ \\
\hline 2 & $\begin{array}{l}\text { Few kilometers } \mathrm{E} \text { of the previous villa, at } \\
\text { the XV miliarium from Venosa. }\end{array}$ & Contrada Tesoro II & Melfi & $\begin{array}{l}\text { Large area of numerous ceramic fragments on the } \\
\text { surface and building of a trapetum. }\end{array}$ & Roman age & $\begin{array}{l}\text { Klein Andreau 1980, p. 350; Volpe } \\
\text { 1990, p. 144, n. } 243 .\end{array}$ \\
\hline 3 & $\begin{array}{l}\text { On the hill immediately SW of Masseria } \\
\text { Leonessa, } 500 \mathrm{~m} \text { from the XVI miliarium } \\
\text { from Venosa. }\end{array}$ & LeONESSA, II & Melfi & $\begin{array}{l}\text { Structures in brickwork visible for at least } 30 \text { rows } \\
\text { of bricks. They are probably the thermal bath of a } \\
\text { villa. }\end{array}$ & Imperial age & Volpe 1990, p. 144, n. 244 \\
\hline 4 & $\begin{array}{l}7 \mathrm{~km} \text { NE of Melfi and } 300 \mathrm{~m} \text { NE of the } \\
\text { XII miliarium from Venosa. }\end{array}$ & $\begin{array}{l}\text { SAN Nicola di } \\
\text { MelFi-SerRa deI } \\
\text { CANONICI }\end{array}$ & Melfi & $\begin{array}{l}\text { On a hill bordering the southern side of the } \\
\text { Ofanto valley, there is a Roman villa of large } \\
\text { dimensions with several phases. An apsidated } \\
\text { room with a residential function belongs to the } \\
\text { Late Antiquity. In the pars rustica dolia and } \\
\text { manual granary mills. }\end{array}$ & $\begin{array}{l}\text { From Late Hellenistic and } \\
\text { Republican to the Late } \\
\text { Antiquity }\end{array}$ & $\begin{array}{c}\text { Nava 2001, pp. } 971-975 ; \text { Nava 2004, } \\
\text { pp. 366-371. }\end{array}$ \\
\hline 5 & $\begin{array}{l}2.5 \mathrm{~km} \mathrm{~S} \text { of Lavello and } 2500 \mathrm{~m} \mathrm{NE} \text { of } \\
\text { the IV miliarium from Venosa. }\end{array}$ & Lamia di Turi & Lavello & $\begin{array}{l}\text { In a large plateau overlooking the Griccioli valley, } \\
\text { not far from the Tratturo Regio Melfi- } \\
\text { Castellaneta, there is an area with fragments of } \\
\text { trachyte millstones, dolia, sealed, black paint, and } \\
\text { common ceramics. }\end{array}$ & $\begin{array}{l}\text { Late Republican and early } \\
\text { Imperial age }\end{array}$ & Volpe 1990, p. 154, n. 279. \\
\hline 6 & $\begin{array}{l}2.7 \mathrm{~km} \mathrm{~S} \text { of Lavello and } 2700 \mathrm{~m} \mathrm{NE} \text { of } \\
\text { the IV miliarium from Venosa. }\end{array}$ & Piani di Scaccia & Lavello & $\begin{array}{l}\text { Not far from the Tratturo Regio Melfi- } \\
\text { Castellaneta emerges an area with fragments of } \\
\text { trachyte millstones, bricks, traces of opus spicatum, } \\
\text { common pottery. }\end{array}$ & Roman age & Volpe 1990, p. 154, n. 280. \\
\hline 7 & $\begin{array}{l}3 \mathrm{~km} \mathrm{SW} \text { of Lavello and } 1700 \mathrm{~m} \mathrm{~N} \text { of the } \\
\text { IV miliarium from Venosa. }\end{array}$ & $\begin{array}{l}\text { FontANA Di } S . \\
\text { BARBATO }\end{array}$ & Lavello & $\begin{array}{l}\text { Area with ceramic fragments, bricks, dolia, } \\
\text { trachyte mills, loom weights, masonry walls. }\end{array}$ & $\begin{array}{l}\text { Late Republican and Late } \\
\text { Antiquity }\end{array}$ & Volpe 1990, p. 154, n. 281. \\
\hline 8 & $\begin{array}{l}4 \mathrm{~km} \mathrm{SE} \text { of Lavello and } 2700 \mathrm{~m} \text { ENE of } \\
\text { the III miliarium from Venosa. }\end{array}$ & Masseria Chiengo & Lavello & $\begin{array}{l}\text { On a hill overlooking the river of Venosa, not far } \\
\text { from the Tratturo Regio Melfi-Castellaneta, there } \\
\text { is an area with fragments of trachyte grindstone, } \\
\text { bricks, opus spicatum floor. }\end{array}$ & Late Antiquity & Volpe 1990, pp. 154-155, n. 282. \\
\hline 9 & $\begin{array}{l}4 \mathrm{~km} \mathrm{SE} \text { of Lavello and } 2500 \mathrm{~m} \mathrm{NE} \text { of the } \\
\text { IV miliarium from Venosa. }\end{array}$ & Sterpare & Lavello & $\begin{array}{l}\text { Area with black-painted ceramic fragments, } \\
\text { bricks, dolia, trachyte millstones. }\end{array}$ & Late Republican & Volpe 1990, p. 155, n. 285. \\
\hline 10 & $\begin{array}{c}2 \mathrm{~km} \mathrm{~N} \text { of Venosa and } 1000 \mathrm{~m} \text { to NE of I } \\
\text { miliarium from Venosa. }\end{array}$ & Piano Regio & VENOSA & $\begin{array}{l}\text { On the top of a plateau is an area of } \\
\text { fragments—-2000 } \mathrm{m}^{2} \text { (bricks, ceramics, fragments } \\
\text { of mosaic pavement). }\end{array}$ & $\begin{array}{l}\text { Triumviral and Late } \\
\text { Antiquity }\end{array}$ & Marchi, Sabbatini 1996, p. 45, n. 167. \\
\hline
\end{tabular}




\begin{tabular}{|c|c|c|c|c|c|c|}
\hline Villa & Position & Site & Municipality & Description & Cronology & References \\
\hline 11 & $\begin{array}{c}2.5 \mathrm{~km} \mathrm{NW} \text { of Venosa and } 700 \mathrm{~m} \mathrm{~N} \text { of II } \\
\text { miliarium from Venosa. }\end{array}$ & Piano Regio & VENOSA & $\begin{array}{l}\text { On the top and slopes of a plateau, there are three } \\
\text { areas of fragments. The largest measures } 1000 \mathrm{~m}^{2} \\
\text { (dolia, grain millstones, ceramic fragments and } \\
\text { bricks). }\end{array}$ & $\begin{array}{l}\text { From Republican to Late } \\
\text { Antiquity }\end{array}$ & $\begin{array}{c}\text { Marchi, Sabbatini 1996, p. 45, nn. } \\
\text { 170-171-172. }\end{array}$ \\
\hline 12 & $\begin{array}{l}1.8 \mathrm{~km} \mathrm{NW} \text { of Venosa and } 300 \mathrm{~m} \mathrm{SE} \text { of } \\
\text { the II miliarium from Venosa. }\end{array}$ & Toppo di Costanza & Venosa & $\begin{array}{l}\text { On the top and along the northern slope of the hill } \\
\text { overlooking the Vallone Contista. Two areas of } \\
\text { fragments-the largest } 2000 \mathrm{~m}^{2} \text { (grain mills, dolia, } \\
\text { ceramics, bricks, columns). Villa with the } \\
\text { residential area with a rustic par. }\end{array}$ & $\begin{array}{l}\text { From Republican to Late } \\
\text { Antiquity }\end{array}$ & $\begin{array}{l}\text { Marchi, Sabbatini 1996, pp. } 45-46, \\
\text { nn. } 178-179 .\end{array}$ \\
\hline 13 & $\begin{array}{l}1.5 \mathrm{~km} \text { WSW of Venosa and } 800 \mathrm{~m} \mathrm{~S} \text { of } \\
\text { the I miliarium from Venosa to the statio } \\
\text { of Pisandes. }\end{array}$ & S. Felice & VENOSA & $\begin{array}{l}\text { Fragment areas found on the SE slopes of a hill. } \\
\text { The largest measure with } 1000 \mathrm{~m}^{2} \text { (bricks and } \\
\text { ceramics, fragments of floors in opus spicatum and } \\
\text { signinum). }\end{array}$ & $\begin{array}{l}\text { From Republican to Late } \\
\text { Antiquity }\end{array}$ & Marchi, Sabbatini 1996, p. 81, n. 459. \\
\hline 14 & $\begin{array}{l}5 \mathrm{~km} \mathrm{SW} \text { of Lavello and between the V } \\
\text { and VI miliarium from Venosa to Ofanto. }\end{array}$ & LAgo del Rendina & Rapolla & $\begin{array}{l}\text { In the area of the lake, masonry structures in opus } \\
\text { incertum, a threshold, various layers of collapse } \\
\text { and numerous ceramic and brick artefacts, } \\
\text { trachyte millstones. }\end{array}$ & $\begin{array}{l}\text { Republican, Imperial, and } \\
\text { Late Antiquity }\end{array}$ & Volpe 1990, p. 145, n. 249. \\
\hline 15 & $\begin{array}{c}1 \mathrm{~km} \mathrm{~N} \text { of Ginestra, and at the VI } \\
\text { miliarium from Venosa to the statio of } \\
\text { Pisandes. }\end{array}$ & Serra del Tesoro & Ginestra & $\begin{array}{l}\text { Along a cattle track that connects Venosa to } \\
\text { Ginestra, Ripacandida and Atella, were found a } \\
\text { marble floor of a large rectangular room, } \\
\text { suspensurae bricks (thermal plant), fragments of a } \\
\text { clay tube and a tile with L. MATI stamp. }\end{array}$ & Imperial age & $\begin{array}{l}\text { Lacava 1889, p. 230; Buck 1971, } \\
\text { Salvatore 1984, p. 29, n. 27; Volpe } \\
\text { 1990, p. 147, n. } 254 .\end{array}$ \\
\hline 16 & $\begin{array}{l}2.8 \mathrm{~km} \text { ENE of Atella and at the XIV } \\
\text { miliarium from Venosa to Potenza, at the } \\
\text { statio of Pisandes. }\end{array}$ & TORRE DEGLI EMBRICI & $\begin{array}{l}\text { RIONERO IN } \\
\text { VULTURE }\end{array}$ & $\begin{array}{l}\text { In this site, identifiable with the statio of Pisandes, } \\
\text { were found a marble of Afrodite with drapery } \\
\text { and a tile with the EMINALIS.M stamp. } \\
\text { Subsequent excavations have found a villa with } \\
\text { four construction phases. In the first (II century } \\
\text { B.C.-I century A.D.) the baths were built. In the } \\
\text { second thereis a general monumentalization } \\
\text { (II-III A.D.). In the third (III-IV century A.D.) } \\
\text { many buildings are added, including an apsidal } \\
\text { room. Finally, the fourth phase sees the } \\
\text { construction of a small quadrangular room. }\end{array}$ & $\begin{array}{l}\text { From the II century B.C. to } \\
\text { the VII century A.D. }\end{array}$ & $\begin{array}{l}\text { Capano 1992, pp. 28-29; Frisone } \\
\text { 2001, pp. 178-180; Nava 2004, pp. } \\
\text { 365-366; Nava, Cracolici, Fletcher } \\
\text { 2005, pp. 209-220; Osanna 2008, pp. } \\
\text { 937-938; De Siena 2010, pp. 623-625. }\end{array}$ \\
\hline 17 & $\begin{array}{l}1.5 \mathrm{~km} \text { ESE of Atella and } 600 \mathrm{~m} \text { E of I } \\
\text { miliarium from Pisandes to Potenza. }\end{array}$ & MAGNONE & Atella & $\begin{array}{l}\text { Pars rustica of a villa (large rectangular room with } \\
\text { pithoi and a smaller one near it). The sarcophagus } \\
\text { of Metilia Torquata (CIL, IX, 658) was found in the } \\
\text { area. }\end{array}$ & $\begin{array}{l}\text { Late II-early III century } \\
\text { A.D. }\end{array}$ & $\begin{array}{l}\text { Salvatore 1981, pp. 956-962; } \\
\text { Simpson 1983, pp. 125-130; } \\
\text { Salvatore 1984, p. 14; pp. 28-29, n. } \\
\text { 23; Volpe 1990, pp. } 145-146, \text { n. } 250 .\end{array}$ \\
\hline
\end{tabular}



Grazie). The use of triclinium is suggested by the particular ornamental scheme (craters and

$18 \quad 1.8 \mathrm{~km} \mathrm{NW}$ of Potenza and the same from the XI miliarium from Pisandes.

Potenza

baskets full of fruit). On the short side $\mathrm{N}$ of the room, there is an apsed raised area with another mosaic with geometric decorative motifs. Around it there is a series of rooms with internal access (cubicula, service and production rooms, kitchen with millstone).

Villa no longer visible but inferable from the sources: «Excavations carried out at the Contrada

19 Within the current western urban area, at the XI miliarium from Pisandes.

Murata

Potenza Murata in the property of doctor Ricciuti on the banks of the Basento. From the excavations carried out I was able to uncover the ruins of a grandiose Roman dwelling with opus signinum

$$
\text { floors». }
$$
$\begin{array}{llr}\text { Within the current southern urban area, STAZIONE INFERIORE } & \text { Potla with atrium and impluvium, decorated with a } \\ (3 \times 3.50 \mathrm{~m}) \text { radial geometric mosaic. Today no }\end{array}$ at the XII miliarium from Pisandes.

(TIRO A SEGNO) longer visible.

On the slopes of a hill called la Rocca are the remains of a Roman villa (walls in opus incertum

$3 \mathrm{~km} \mathrm{~W}$ of Pignola, at the $\mathrm{V}$ miliarium of

Le TEGOLE

Pignola with bricks maked HELENI, OSID and HVB, Herculia, from Potenza. with bricks marked HELENI, OSID and HVB, traces of aqueduct, fragments of dolia, sealed
ceramic and coins dating back to the Caligula and Nerone age). It is probably an imperial property.

Down Mount Volturino and near the Molinara tream, the villa is built around a large courtyard.

$1.8 \mathrm{~km} \mathrm{~W}$ of Marsicovetere and $1350 \mathrm{~m}$ $\mathrm{NE}$ of the VI miliarium from Acidios.

Three service rooms open to the $\mathrm{N}$ and a production area to the $\mathrm{S}$. To the $\mathrm{W}$ of the courtyard there is the pars urbana of the villa.

Cronology

Lattanzi, 1974, pp. 272-274; Capano, 1987, pp. 49-70; Di Giuseppe, 1996

From the III to the VI pp. 223-224; Gualtieri, 2003, pp. century A.D. 243-247; De Siena, 2007, pp. 407-463;

Di Noia, 2008, pp. 68-71; Donnici 2017, pp. 1-19.

APPZ, b. 257, fasc. 1: Lettera del 10 novembre 1901 (con data di arrivo 14 novembre 1901), del Direttore del

useo Archeologico Provinciale Di Cicco al Presidente della Deputazione Provinciale 


\begin{tabular}{|c|c|c|c|c|c|c|}
\hline Villa & Position & Site & Municipality & $\begin{array}{l}\text { Description } \\
\end{array}$ & Cronology & References \\
\hline 23 & $\begin{array}{l}3 \mathrm{~km} \text { from Marsicovetere, at the } \mathrm{VI} \\
\text { miliarium from Acidios. }\end{array}$ & Pedali Le Grotte & Marsicovetere & $\begin{array}{l}\text { The villa, built in the I century A.D., has two } \\
\text { phases: The first ends with an earthquake; the } \\
\text { second in the V A.D., when the villa was finally } \\
\text { abandoned. }\end{array}$ & $\begin{array}{c}\text { From the I to the } V \text { century } \\
\text { A.D. }\end{array}$ & $\begin{array}{l}\text { Russo, Gargano, Di Giuseppe 2007, p. } \\
\text { 86; Russo, Guerrini 2009, pp. 78-79. }\end{array}$ \\
\hline 24 & $\begin{array}{c}1.5 \mathrm{~km} \text { NW of Viggiano and } 2300 \mathrm{~m} \mathrm{NE} \\
\text { of XI miliarium from Acidios. }\end{array}$ & MaIORANo & VIGGIANO & $\begin{array}{l}\text { Along one of the roads linking the Basento valley } \\
\text { and the Val d'Agri is a structure composed of five } \\
\text { rooms, of which the central one is an apse, } \\
\text { probably equipped with wall mosaics. } \\
\text { Another environment, uncovered, aligned with } \\
\text { the apse is equipped with a central fountain. The } \\
\text { rooms have polychrome mosaic floors. }\end{array}$ & Late antique age & $\begin{array}{l}\text { Nava 2004, pp. 952-955; Russo 2005, } \\
\text { pp. 241-256; Russo, Gargano, Di } \\
\text { Giuseppe 2007, p. 86; Russo, } \\
\text { Guerrini 2009, pp. 78-79. }\end{array}$ \\
\hline
\end{tabular}




\section{Appendix B. Archaeological Notes of Appendix A}

Adamesteanu, D., La Basilicata antica. Storia e monumenti, Cava dei Tirreni. 1974.

Buck, R.J., The Via Herculia, in BSR, XXXIX, 1971, pp. 66-87.

Capano, A. La villa romana di contrada "Malvarcaro di Potenza". Proposte di lettura dopo i primi scavi archeologici (1974 e 1978-1979), in BollStoBas, 1987, pp. 49-70.

Capano, A. (a cura di), Beni culturali a Potenza, Agropoli (SA), 1989.

Capano, A. Torre degli Embrici. Statuetta di Afrodite, in de Lachenal, L. (a cura di), Da Leukanía a Lucania. La Lucania centro-orientale fra Pirro e $i$ Giulio-Claudii, Catalogo della Mostra, Roma, 1992, pp. 28-29.

De Siena, A. L'attività archeologica in Basilicata nel 2006, in Atti Taranto, XLVII, Napoli, 2007, pp. 407-463.

De Siena, A. Attività della Soprintendenza per i Beni Archeologici della Basilicata, in Atti Taranto 2009, Taranto 2010, 2010, pp. 609-656.

Di Cicco, V. Scoperta di un "pago" dell'età romana, in NSc, II, Serie VI, 1926, pp. 442-444.

Di Giuseppe, H., Insediamenti rurali della Basilicata interna tra la romanizzazione e l'età tardoantica: materiali per una tipologia, in Epigrafia e territorio. Politica e società. Temi di antichità romane, IV, Bari, 1996, pp. 189-252.

Di Giuseppe, H., Russo, A. Instrumenta inscripta dalla villa romana di Barricelle in Lucania, in SEBarc X, 2012, pp. 405-423.

Di Noia, A., Potentia. La città romana tra età repubblicana e tardo antica, I Quaderni del Consiglio Regionale della Basilicata, Melfi (Pz). 2008.

Donnici, F. Testimonianze pavimentali da Potentia e dal suo ager suburbanus, in AISCOM Bollettino online, 2017, 1, pp. 1-19.

Fiorelli, G., Pignola, in NSc, 1883, pp. 378-379.

Frisone, F., s.v. Rionero in Vulture, in BTCG, Pisa-Roma-Napoli, 2001, pp. 178-180.

Gargano, M.P. La villa romana di Marsicovetere-Barricelle (Potenza), in Tarlano, F. (a cura di), Il territorio grumentino e la Valle dell'Agri nell'antichità, Atti della Giornata di Studi (Grumento Nova, Potenza, 25 Aprile 2009), 2009, pp. 67-76. Greco, C., Attività della Soprintendenza per i Beni Archeologici della Basilicata, in Atti Taranto 2008, Taranto 2009, 2009,pp. 787-824.

Gualtieri, M., La Lucania romana. Cultura e società nella documentazione archeologica, Quaderni di Ostraka, 8, Napoli, 2003, pp. 243-247.

Klein Andreau, C., La romanizzazione, in Civiltà antiche del medio Ofanto, Napoli, 1976, pp. 30-36.

Lacava, M. Barile e Ripacandida, in Nsc, 1889, pp. 229-230.

Lattanzi, E. Scavi a Timmari, Potenza e Tolve, in Atti Taranto, 1974, pp. 269-275.

Marchi, M.L., Sabbatini, G. Venusia (IGM 187 I NO/NE), Forma Italiae, 37, Firenze. 1996.

Nava, M.L. L'attività archeologica in Basilicata nel 2000, in Atti Taranto 2000, Taranto 2001, pp. 939-980.

Nava, M.L. L'attività archeologica in Basilicata nel 2003, in Atti Taranto 2003, Taranto 2004, pp. 935-1005.

Nava, M.L., Cracolici, V., Fletcher, R., La romanizzazione della Basilicata nord-orientale tra Repubblica e Impero, in Atti del $25^{\circ}$ Convegno Nazionale sulla Preistoria, Protostoria e Storia della Daunia (San Severo, 3-5 Dicembre 2004), a cura di Gravina, A., San Severo (FG), 2005, pp. 209-220.

Osanna, M. L'attività archeologica in Basilicata nel 2007, in Atti Taranto 2007, Taranto 2008, pp. 911-944.

Russo, A. I mosaici della villa tardo-antica di località Maiorano di Viggiano (Potenza). Rapporto preliminare, in Angelelli C. (a cura di), Atti del X Colloquio AISCOM, Lecce 18-21 febbraio 2004, Roma, 2005, pp. 241-256.

Russo, A., Modalità insediative in alta Val d'Agri tra IV e III secolo a.C., in Tarlano F. (a cura di), Il territorio grumentino e la Valle dell'Agri nell'antichità, Atti della Giornata di Studi (Grumento Nova, Potenza, 25 Aprile 2009), Grumento Nova (PZ), 2009, pp. 45-48.

Russo, A., Gargano, M.P., Di Giuseppe, H., Dalla villa dei Bruttii Praesentes alla proprietà imperiale. Il complesso archeologico di Marsicovetere - Barricelle (PZ), in Siris 8, 2007, pp. 81-119.

Russo, A., Guerrini, P. L'alta valle dell'Agri (PZ) tra Tardoantico e Altomedioevo. I nuclei funerari, in Temporis Signa, IV. 2009, pp. 75-110. 
Salvatore, M.R., Antichità altomedievali in Basilicata, in Atti del Convegno La cultura in Italia tra tardoantico e altomedioevo. Stato e prospettive delle ricerche (Roma 1979), Roma 1981, pp. 947-964.

Salvatore, M.R. (a cura di), Venosa: un parco archeologico e un museo. Come e perché, Catalogo della mostra tenutasi a Venosa (24 Settembre-13 Ottobre 1984), Taranto.

Simpson, C.J., La villa romana di Atella: sondaggi preliminari, in Atti della Tavola Rotonda Lo scavo di San Giovanni di Ruoti ed il periodo tardo-antico in Basilicata (Roma 1981), Bari, 1983, pp. 125-130.

Small, A.M., L'occupazione del territorio in età romana, in Adamesteanu, D. (a cura di), Storia della Basilicata. L'Antichità, Bari, 1999, pp. 559-600; 582.

Tagliente, M., s.v. Melfi, in BTCG, Pisa-Roma, 1991, pp. 534-540.

Valente, C. (a cura di), La mia Basilicata, Sambuceto. 1989

Volpe, G., La Daunia nell'età della romanizzazione. Paesaggio agrario, produzione, scambi, Bari. 1990.

\section{References}

1. Carreras, C.; De Soto, P. The roman transport network: A precedent for the integration of the European mobility. Hist. Methods 2013, 46, 117-133. [CrossRef]

2. Tsokas, G.N.; Tsourlos, P.I.; Stampolidis, A. Tracing a major roman road in the area of ancient Helike by resistivity tomography. Archaeol. Prospect. 2009, 16, 251-266. [CrossRef]

3. Warmuth, V.M.; Campana, M.G.; Eriksson, A.; Bower, M.; Barker, G.; Manica, A. Ancient trade routes shaped the genetic structure of horses in eastern Eurasia. Mol. Ecol. 2013, 22, 5340-5351. [CrossRef] [PubMed]

4. Xeidakis, G.S.; Varagouli, E.G. Design and construction of Roman roads: The case of Via Egnatia in the Aegean Thrace, northern Greece. Environ. Eng. Geosci. 1997, 3, 123-132. [CrossRef]

5. Di Luzio, E.; Carfora, P. Geomorphological records of diachronous quarrying activities along the ancient Appia route at the Aurunci Mountain pass (Central Italy). Geomorphology 2018, 306, 210-223. [CrossRef]

6. Del Lungo, S. Topografia e antichità della via Herculia in Basilicata, tra leggenda e realtà. In La via Herculia, storia, territorio, sapori; Sabia, C.A., Sileo, R., Eds.; Grafiche Zaccara: Lagonegro, Italy, 2013; pp. 15-89.

7. Buck, R.J. The via Herculia. Br. Sch. Rome 1971, 39, 66-87. [CrossRef]

8. Lazzari, M.; Gioia, D. Geologia, geomorfologia e viabilità antica: il caso della via Herculia in Basilicata. In Lungo la Via Herculia. Storia, Territorio, Sapori; Sabia, C.A., Sileo, R., Eds.; Grafiche Zaccara: Lagonegro, Italy, 2013; pp. 91-118.

9. Quilici, L. La via Appia attraverso la gola di Itri. Atlante Temat. Di Topogr. Antica 1999, 8, 52-94.

10. Rosada, G. Tecnica stradale e paesaggio nella Decima Regio. Atlante Temat. Di Topogr. Antica 1992, 1, 39-50.

11. Ceraudo, G. A proposito delle lastre iscritte dei ponti della via Traiana. Atlante Temat. Di Topogr. Antica 2012, 1, 83-92.

12. Del Lungo, S. La Lucania tardoantica nella Tabula Peutingeriana alla luce delle fonti gromatiche. MEFRA 2017, 129, 635-662.

13. Quilici, L. La via Salaria da Roma all'alto Velino. La tecnica costruttiva dei manufatti romani. Atlante Temat. Di Topogr. Antica 1993, 2, 85-154.

14. Biocco, E. Il diverticolo della Flaminia ab Nuceria ad Anconam nel territorio di Pioraco (Prolaque). Atlante Temat. Di Topogr. Antica 2009, 19, 81-91.

15. Quilici, L. Praetorium Speluncae. Ricerche sui confini della proprietà imperiale. Atlante Temat. Di Topogr. Antica 2009, 19, 201-325.

16. Quilici, L. Sul calcestruzzo della strada che da Norba scende alla Piana Pontina. Atlante Temat. Di Topogr. Antica 2000, 9, 245-250.

17. Lazzari, M.; Gioia, D. UAV images and historical aerial-photos for geomorphological analysis and hillslope evolution of the Uggiano medieval archaeological site (Basilicata, southern Italy). Geomat. Nat. Hazards Risk 2017, 8, 104-119. [CrossRef]

18. Giuliani, C.F. Il Clivus Tiburtinus ed il sistema stradale connesso. Atlante Temat. Di Topogr. Antica 1992, 1, 33-38.

19. Lazzari, M. Note Illustrative Della Carta Inventario Delle Frane Della Basilicata Centroccidentale; Editore Zaccara: Lagonegro, Italy, 2011. 
20. Lazzari, M.; Gioia, D. Regional-scale landslide inventory, central-western sector of the Basilicata region (Southern Apennines, Italy). J. Maps 2016, 12, 852-859. [CrossRef]

21. Lazzari, M.; Gioia, D.; Anzidei, B. Landslide inventory of the Basilicata region (Southern Italy). J. Maps 2018, 14, 348-356. [CrossRef]

22. Schiattarella, M.; Giano, S.I.; Gioia, D. Long-term geomorphological evolution of the axial zone of the Campania-Lucania Apennine, southern Italy: A review. Geol. Carpathica 2017, 68, 57-67. [CrossRef]

23. Boenzi, F.; Capolongo, D.; Cecaro, G.; D’Andrea, E.; Giano, S.I.; Lazzari, M.; Schiattarella, M. Morphostructural evolution and uplift rates of the western side of the upper Agri River valley, southern Apennines, Italy. Boll. Della Soc. Geol. Ital. 2004, 123, 357-372.

24. Capolongo, D.; Cecaro, G.; Giano, S.I.; Lazzari, M.; Schiattarella, M. Structural control on drainage network of the south-western side of the Agri River upper valley (Southern Apennines, Italy). Geogr. Fis. E Din. Quat. 2005, 28, 169-180.

25. Giannandrea, P.; La Volpe, L.; Principe, C.; Schiattarella, M. Unconformity-bounded stratigraphic units and evolutionary history of the middle Pleistocene Monte Vulture volcano, southern Apennines, Italy. Boll. Della Soc. Geol. Ital. 2006, 125, 67-92.

26. Schiattarella, M.; Di Leo, P.; Beneduce, P.; Giano, S.I. Quaternary uplift vs tectonic loading: A case study from the Lucanian Apennine, southern Italy. Quat. Int. 2003, 101, 239-251. [CrossRef]

27. Schiattarella, M.; Romeo, M.; Marino, M.; Schiattarella, M. Pliocene to Quaternary evolution of the Ofanto Basin in southern Italy: an approach based on the unconformity-bounded stratigraphic units. Ital. J. Geosci. 2014, 133, 27-44.

28. Coralini, A. Osservazioni sulle gallerie stradali. Atlante Temat. Di Topogr. Antica 1992, 1, 83-92.

29. Coralini, A. Vie in galleria, in tagliata e in trincea nel mondo romano al di fuori dell'Italia peninsulare. In Via per montes excisa; Busana, M.S., Ed.; L'Erma di Bretschneider: Roma, Italy, 1997; pp. 279-335.

30. Gianfrotta, P.A. Mare Tyrrhenum a Lucrino molibus seclusum. Atlante Temat. Di Topogr. Antica 2011, 8, 69-80.

31. Di Giuseppe, H.; Russo, A. Instrumenta inscripta dalla villa romana di Barricelle in Lucania. SEBarc 2012, 10, 405-423.

32. Russo, A. Modalità insediative in alta Val d'Agri tra IV e III secolo a.C. In Il territorio grumentino e la valle dell'Agri nell'antichità. Atti della Giornata di Studi; Tarlano, F., Ed.; BraDypUS: Bologna, Italy, 2009; pp. 45-48.

33. Nava, M.L. L'attività archeologica in Basilicata nel 2003. In Proceedings of the Atti del XLIII Congresso di Studi sulla Magna Grecia, Taranto, Italy, 26-30 September 2003; pp. 935-1000.

34. Lazzari, M.; Pieri, P. Modello stratigrafico-deposizionale della successione regressiva infrapleistocenica della Fossa bradanica nell'area compresa tra Lavello, Genzano e Spinazzola. Mem. Soc. Geol. It. 2002, 57, $231-237$.

35. Lazzari, M. Il comportamento tettonico e sedimentario del bacino d'avanfossa Bradanica durante il Pleistocene inferiore. Mem. Descr. Carta Geol. It. 2008, 77, 61-76.

36. Menardi Noguera, A.; Rea, G. Deep structure of the Campanian-Lucanian Arc (Southern Apennine, Italy). Tectonophysics 2000, 324, 239-265. [CrossRef]

37. Pescatore, T.; Renda, P.; Schiattarella, M.; Tramutoli, M. Stratigraphic and structural relationships between Meso-Cenozoic Lagonegro basin and coeval carbonate platforms in southern Apennines, Italy. Tectonophysics 1999, 315, 269-286. [CrossRef]

38. Patacca, E.; Scandone, P. Geology of the Southern Apennines. Boll. Della Soc. Geol. Ital. Suppl. 2007, 7, 75-119.

39. Longhitano, S.G. Sedimentary facies and sequence stratigraphy of coarse-grained Gilbert-type deltas within the Pliocene thrust-top Potenza Basin (Southern Apennines, Italy). Sediment. Geol. 2008, 210, 87-110. [CrossRef]

40. Schiattarella, M.; Giano, S.I.; Gioia, D.; Martino, C.; Nico, G. Age and statistical properties of the summit palaeosurface of southern Italy. Geogr. Fis. E Din. Quat. 2013, 36, 289-302.

41. Chiarella, D.; Longhitano, S.G.; Tropeano, M. Different stacking patterns along an active fold-and-thrust belt-Acerenza Bay, Southern Apennines (Italy). Geology 2019, 47, 139-142. [CrossRef]

42. Longhitano, S.G.; Sabato, L.; Tropeano, M.; Gallicchio, S. A mixed bioclastic-siliciclastic flood-tidal delta in a micro tidal setting: Depositional architectures and hierarchical internal organization (Pliocene, Southern Apennine, Italy). J. Sediment. Res. 2010, 80, 36-53. [CrossRef]

43. Mollo Mezzena, R. La strada romana in Valle d'Aosta: procedimenti tecnici e costruttivi. Atlante Temat. Di Topogr. Antica 1992, 1, 57-72. 
44. Giano, S.I. Quaternary alluvial fan systems of the Agri intermontane basin (southern Italy): Tectonic and climatic controls. Geol. Carpathica 2011, 62, 65-76. [CrossRef]

45. Lazzari, M.; Gioia, D. Geologia e Geomorfologia lungo la Via ab Regio ad Capuam in Basilicata. In La via ab Regio ad Capuam, Un itinerario culturale come motore dello sviluppo economico e turistico del territorio; Lazzari, M., Caruso, L., Eds.; Grafiche Zaccara: Lagonegro, Italy, 2015; pp. 197-208.

46. Del Lungo, S. La Via ab Regio ad Capuam da Casalbuono a Laino (il comprensorio Lagonegrese e della Valle del Noce): il dato topografico. In La via ab Regio ad Capuam. Un itinerario culturale come motore dello sviluppo economico e turistico del territorio; Caruso, L., Lazzari, M., Eds.; Grafiche Zaccara: Lagonegro, Italy, 2015; pp. 133-152.

(C) 2019 by the authors. Licensee MDPI, Basel, Switzerland. This article is an open access article distributed under the terms and conditions of the Creative Commons Attribution (CC BY) license (http://creativecommons.org/licenses/by/4.0/). 